\title{
磁力選鉱ならびに重液選鉱の操業実績
}

\section{Operation data for magnetic separation and Heavy-fluid separation}

編 集 委 員 編

【I】選 炭 関 係
(A) 三菱鉱業古贺山鉱業所

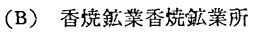

【II】含銅硫化関係
(A) 日本鉣業白滝釯業所
(B) 日本鉱業日立捈業所

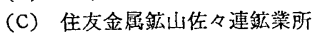
(D) 石原産業紀州铒業所
（E）三菱金属鉣業妙法鉣業所
(F) 三菱金属鉣業墕合森鈗業所
(G) 住友金属鉱山別子鉱業所
(H) 古河鉱業足尾釯業所
(I) 日本鉱業杤木鉱業所

【III】其他
(A) 聚村悇業大谷鉣山
(B) 鉄興社稲倉石鉱業所
(C) 東邦要鉛対州釷業所
(D) 東洋釷山見立鉱業所
(E) 日本鉱業河山釯業所
(F) 同和錴業湘原金業所
(G) 日鉄釯業釜石釯業所
(H) 日本叙業尾小晊鉣業所
（I）うサ釯業田老鉣業所

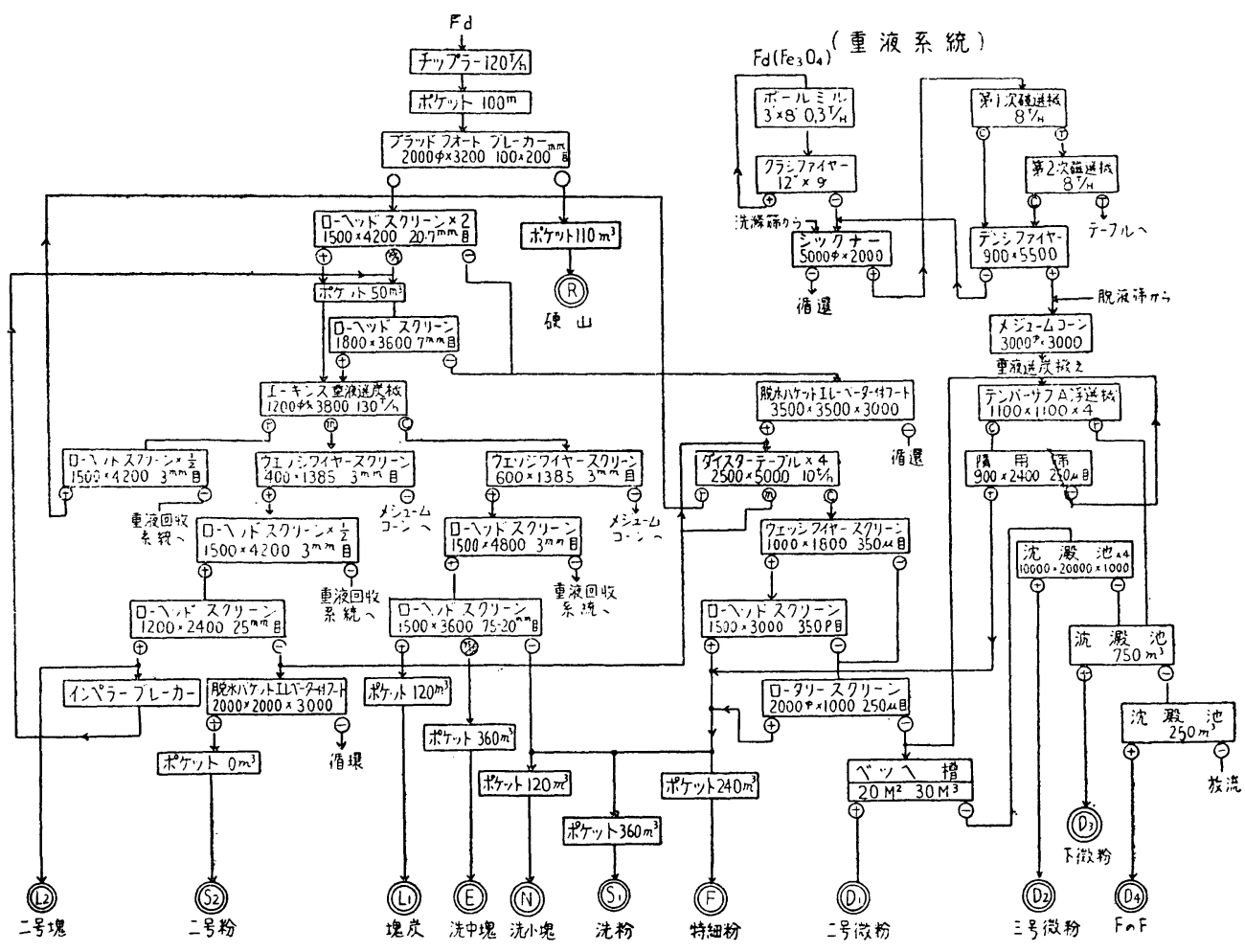

序：第19回例会討議塗料として取繹めたものにそ の後到着を加へ、紙数の関係で一部をカットし適当に配 列変元して見た。表は (1) 石炭、(2) 含銅硫化、(3) 其他 に三大別しその順は大体原稿の到着日付によつた。

\section{【I】選炭関係}

\section{（1）重液選炭系統図}

（A）三菱古賀山鉱業所 第一図、第二図（重液材浄 化回収系統図)

(B) 香燒鉱業所 第三図

(2) 重液選炭成績

（A）三菱古賀山鉱業所 第一表

（3）重液選炭機の種類並に仕様 第二表

（4）磁力選鉱機、マグネタイザー及びデイマグネタイ ザー

第 1 図古賀山選炭工場系統図 


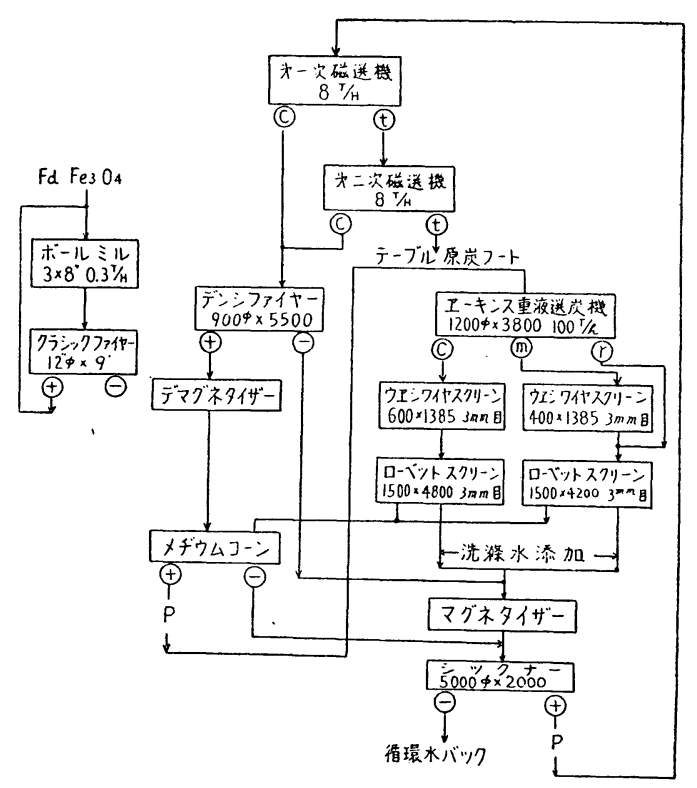

第 2 図 重液材净化回収系統図
第一表 32. 4 月の重液選炭成績

\begin{tabular}{|c|c|c|c|}
\hline 別 & 処理䣩数 & Ash $\%$ & 考 \\
\hline 塊 炭 & 3.392 & 11.0 & $+75 \% / m \quad$ (粒度) \\
\hline 洗中塊炭 & 22.308 & 12.1 & $75 \sim 20 \mathrm{~m} / \mathrm{m}(\mathrm{\prime})$ \\
\hline 洗小塊炭 & 15.815 & 11.8 & $20 \sim 8 \mathrm{~m} / \mathrm{m}(\mathrm{\prime \prime})$ \\
\hline 2 号塊炭 & 704 & 48.0 & \\
\hline 2 号粉炭 & 804 & 47.6 & \\
\hline 硬 & 29.008 & 81.1 & \\
\hline 棓(原炭) & 72.031 & 40.5 & \\
\hline \multicolumn{2}{|l|}{ 運転時間 } & \multicolumn{2}{|c|}{$799^{\circ} \sim 30^{\prime}$} \\
\hline \multicolumn{2}{|l|}{ 原炭処理量 } & \multicolumn{2}{|c|}{$90^{\mathrm{T}} / \mathrm{H}$} \\
\hline \multicolumn{2}{|l|}{ 使用電力量 } & \multicolumn{2}{|c|}{$3.25 \mathrm{~K} . \mathrm{W} . \mathrm{H} /$ 精炭屯当り } \\
\hline \multicolumn{2}{|c|}{ 使用水量 } & \multicolumn{2}{|c|}{$88^{M_{3} / B}$} \\
\hline \multicolumn{2}{|c|}{ マグネタイト使用量 } & \multicolumn{2}{|c|}{$1.3 \mathrm{~kg} /$ 原炭屯当り } \\
\hline
\end{tabular}

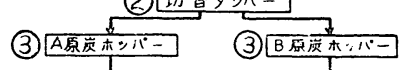

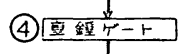

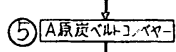
(4) $\frac{1}{1}$
(6) スクレ-パ-

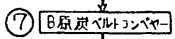
香焼鉱業所選炭采統図

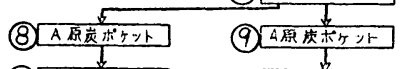

(10) B原莫格计

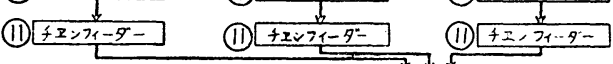

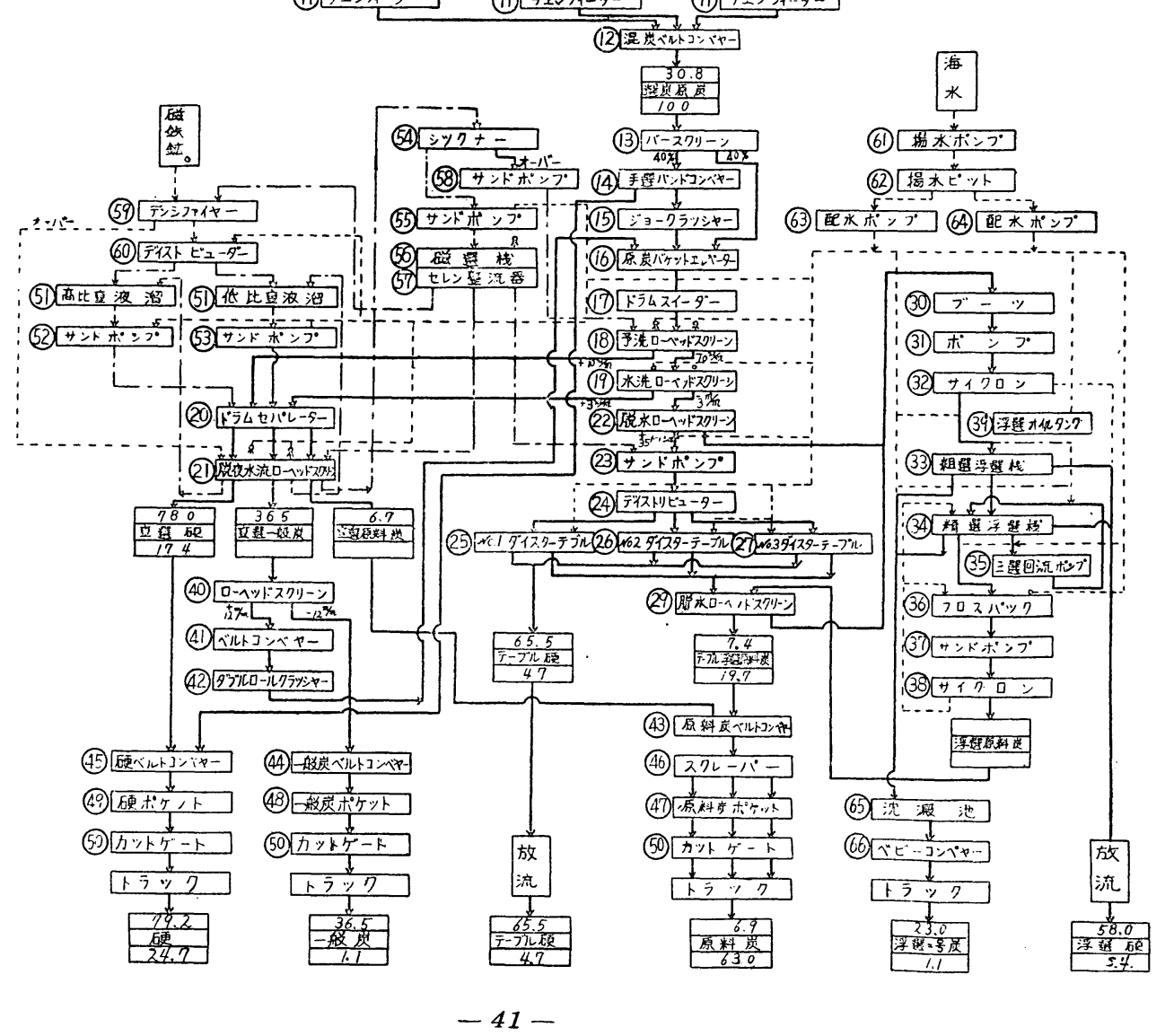


第 二 表

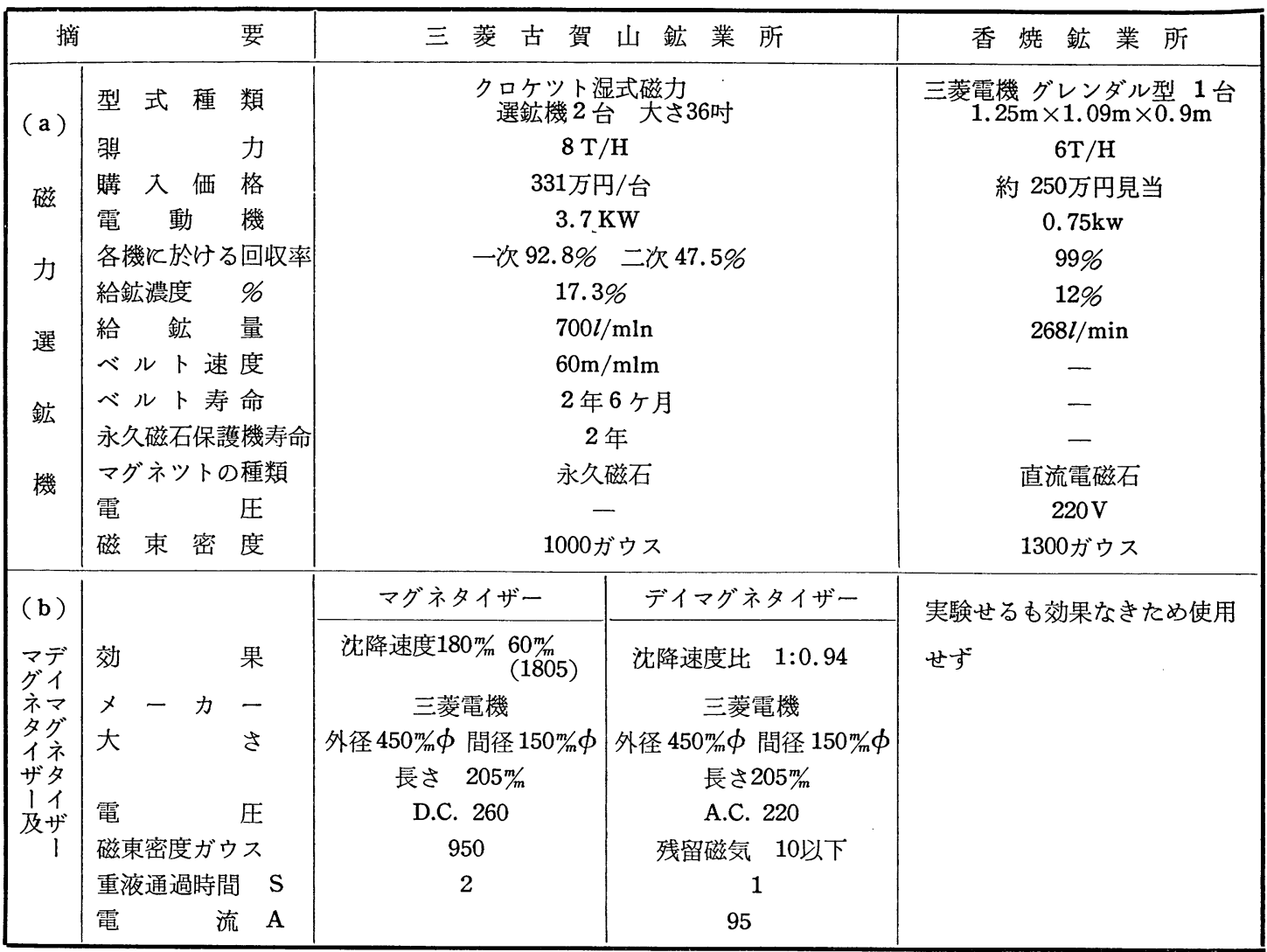

（5）重液材、並にその消費量

第 三 表

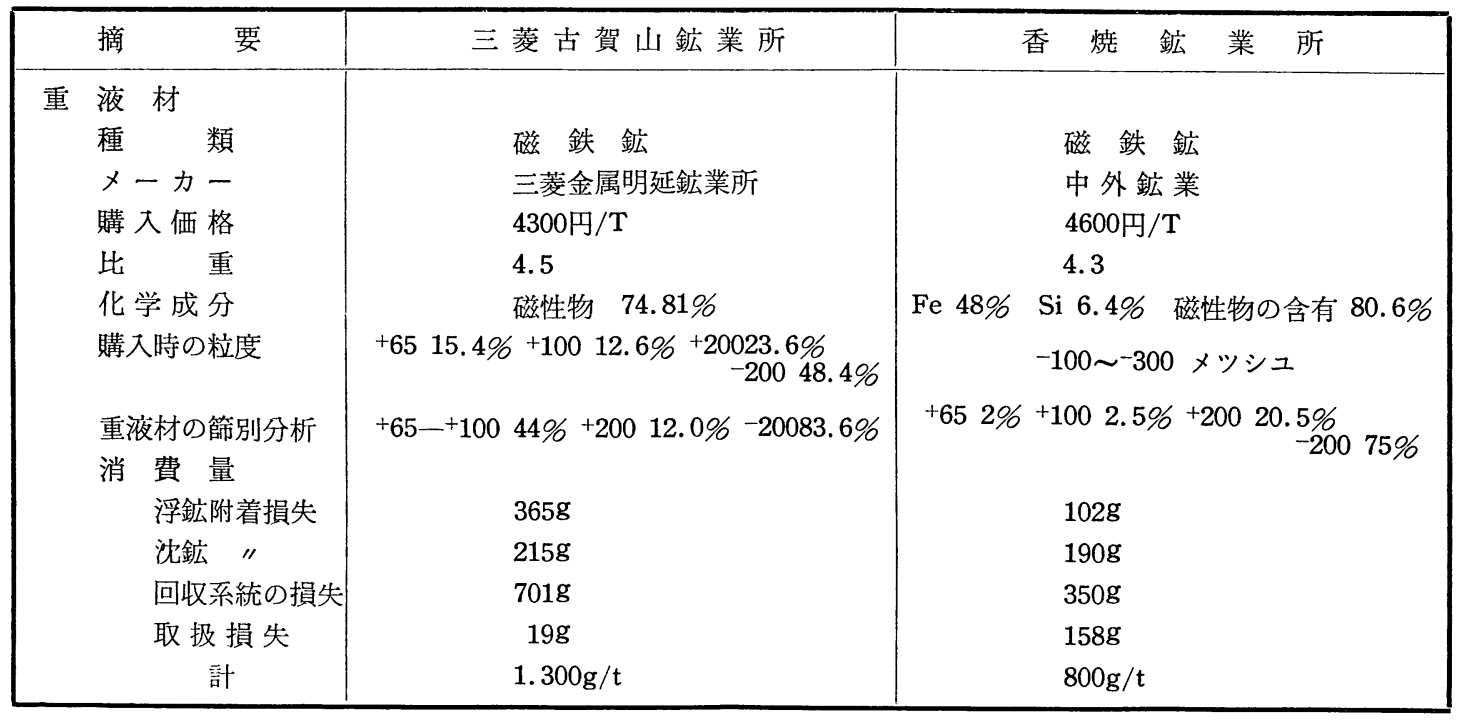




\section{（b）其 の 他}

重液の粘度と安定度について及び粘度と分離効果との 関係等についての考案

古賀山鉱業所飞於いては比粘度 1.4 以下になれば磁鉄 鉱の重液選定機内飞於於沈降速度が急速に增加し、同 上槽内の底部の比重が硬の比重より大となり硬の排出が 不良となる、但し分離は良好、比粒度 2.5 以上の場合は 安定度增大するが、他方 $-8 \frac{m}{m}$ 以下の分離は不良香燒で はこの方式の設備では比粘度は問題々ならないと云う。

\section{（7）現設備の欠陥の点及び今後成績向上の為の対策等 についての意見}

古賀山では現在の設備が篩の点が不充分で重液選炭機 の給炭中にー $8 m / m$ 約 $10 \%$ 混入しているので原炭節を増 設したいと思う。精炭の分離比重は1.58、2 号炭の分離 比重は1.68亿しているが将来 2 号炭の分離比重を增大し 低品位炭の回収を実施し歩留を向上したい。

香焼では重選原鉱ポケツトを持たない事が欠点であ り、このため時々給鉱量が変化しこれが原因で品位に変 動があるのでこれを改良したと思う。

\section{『I】含銅硫化関係}

\section{(1) 重液選鉱系統図}

\section{(A) 日本鉱業白滝鉱業所 第四図}

（B）日本鉱業日立鉱業所 第五図 第六図

（C）住友金属鉱山佐々連釷業所 第七図 第八図

(D) 石原産業紀州釷業所 第九図

（E）三菱金属鉱業妙法鉱業所 第十図 第十一図

(F) " 等合森鉣業所 第十二図 第十三図

（G）住友金属別子鉱業所 第十四図

(H) 古河鉣業足尾釷業所 第十五図 第十六図

（I）日本鉱業杤木鉱業所 第十七図 第十八図

（2）重液選鉱成績（32年 4 月～6 月実績） 第四表

（3）重液選鉱機の種類並に仕様 第五表

\section{（4）磁力選鉱機 第六表}

\section{（5）重液材及びその消費量 第七表}

\section{（6）重液の粘度と安定度について及び粘度と分離効果 との関係等についての考察}

\section{（A）日本鉱業白滝鉱業所}

分離機内の重液の粘性は重液機の微粒の含有割合 (200mesh 60 75\%) 原鉱に附着した粉鈗の累皘（非磁 性物 $7 \%$ 15\%）分離機内でのスパイラル飞よる鉱石微 粉の生成等によつて運転時間に伴つて增加して（比粘度 1.25より1.45）分離成績を低下する直接原因となつてい る。

現在規定比重 $3.00 \pm 0.02$ 範囲で操業しているが、重

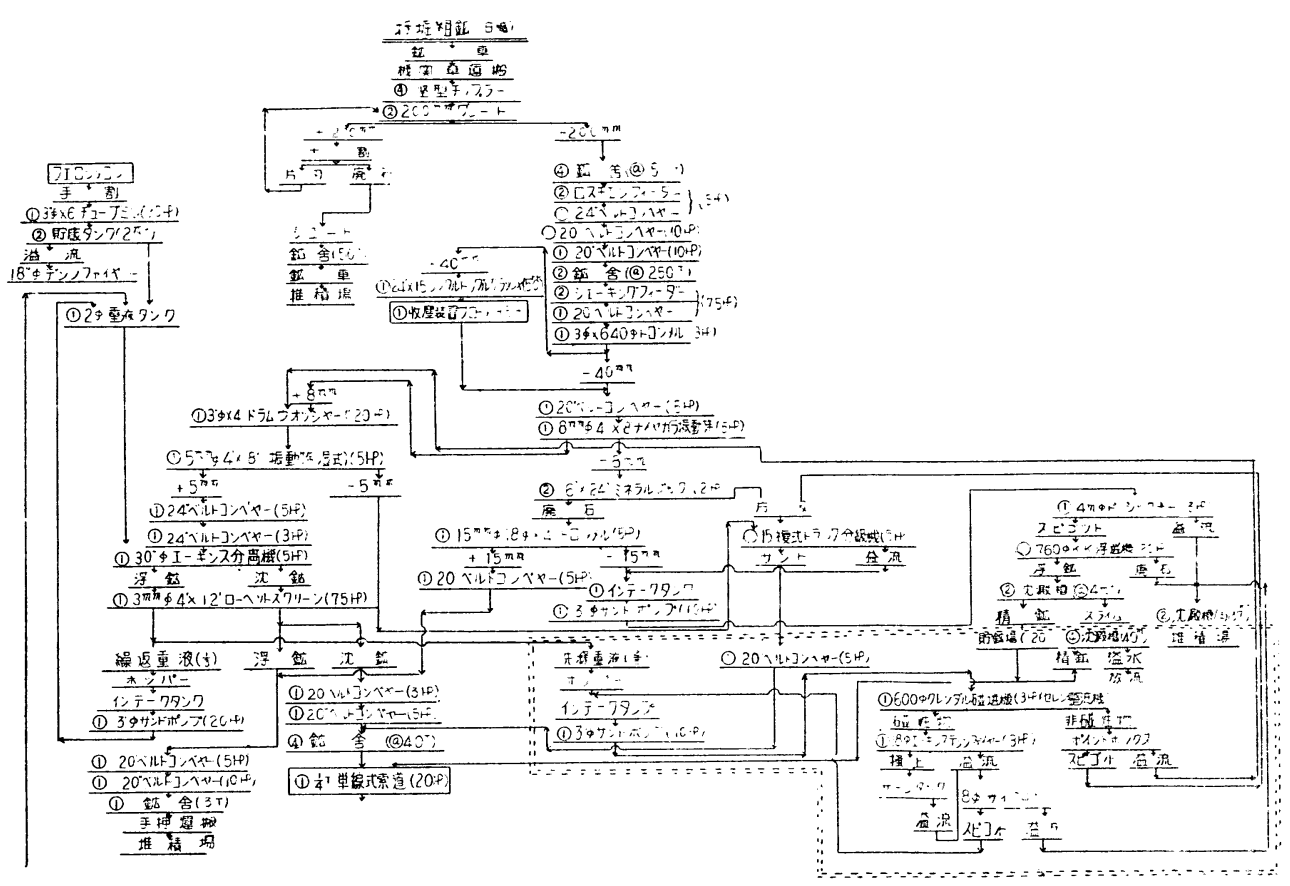

第 図白滝鉱業所重選並に重液材浄化回収系統図 
液精選（月 1 回実施）後 2 週間以降はメヂウムの污染が 上昇する（15 18\%）傾向にあるので現在之が対策とし て、操業中に分離機内の更飞多量の重液を連続的飞取出 して回収系統に送り精選することが好ましいので浮鉱側 ゲートの横の給鉱側飞巾4"ゲード（リップ高さは浮鉱ゲ 一トと同じにし、内側には、浮鉱の”溢出防止のため、3

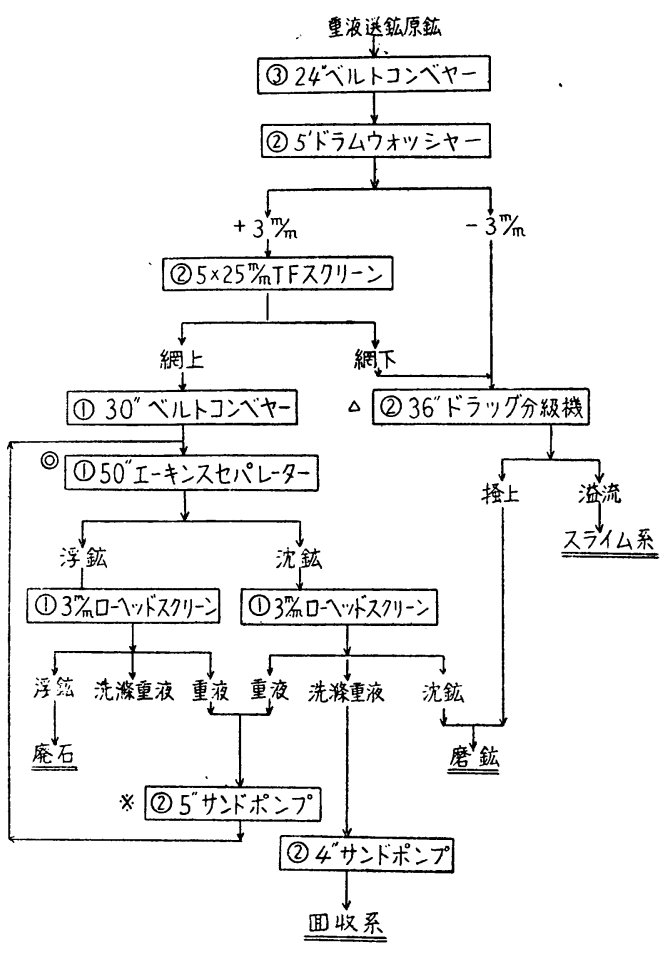

第 5 図 重液選鉱系統図

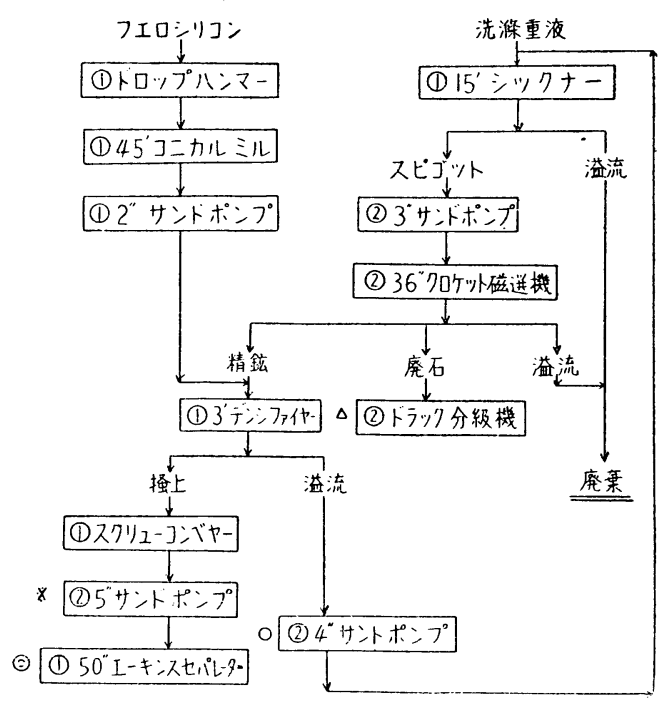

第 6 図 重液材の浄化回収系統図 $m / m$ 中眼鉄板の覆を取付けている）を設け槽液面の粉鉱の 含有多い低比重液を卦出して磁選機济る様飞してい る。之によつて重液の 粘性増加を緩和するとととなり （比粘度1.30 1.33）又運転飞伴う重液比重の低下を防 止している。

尚従来メヂウムシックナーを使用していたがメヂウム の污染防止、微粉化による粘度低下を含めてメヂウムの 微竝恃に除去する意味で之を廃止し原鉱洗䀺スライム シックナーとして切替使用している。

粘度と分離効果との関係は粘度上昇飞伴亏細粒 $5 \mathrm{~m} / \mathrm{m} \sim$ $8 m / m$ 片》鉱の浮鉱への迷い込みが増加して成績低下を来 すが各粘度別の成績は取つてない。

(B) 住友佐々連鉱業所

スライムイよる重液の污濁が高まるにつれ比粘度が大 となりセパレーターの分離精度が悪くなる。例兄ば当所

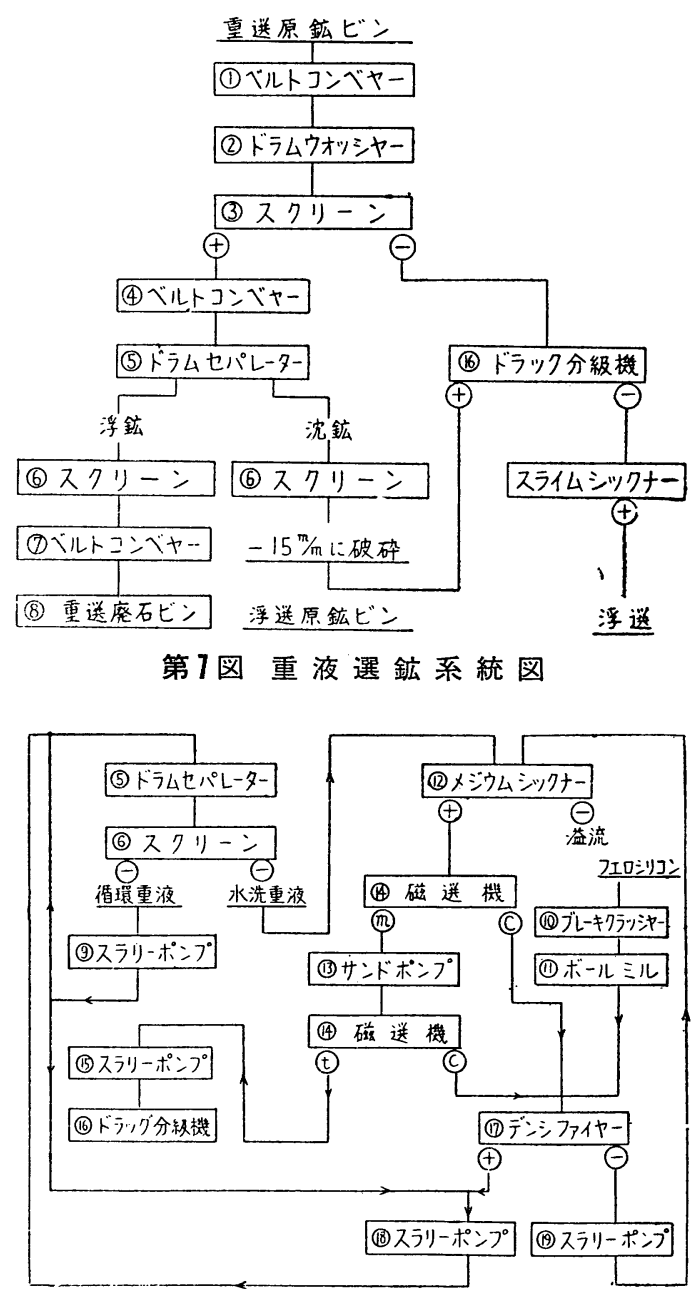

第 8 図 重液材浄化回収系統図 


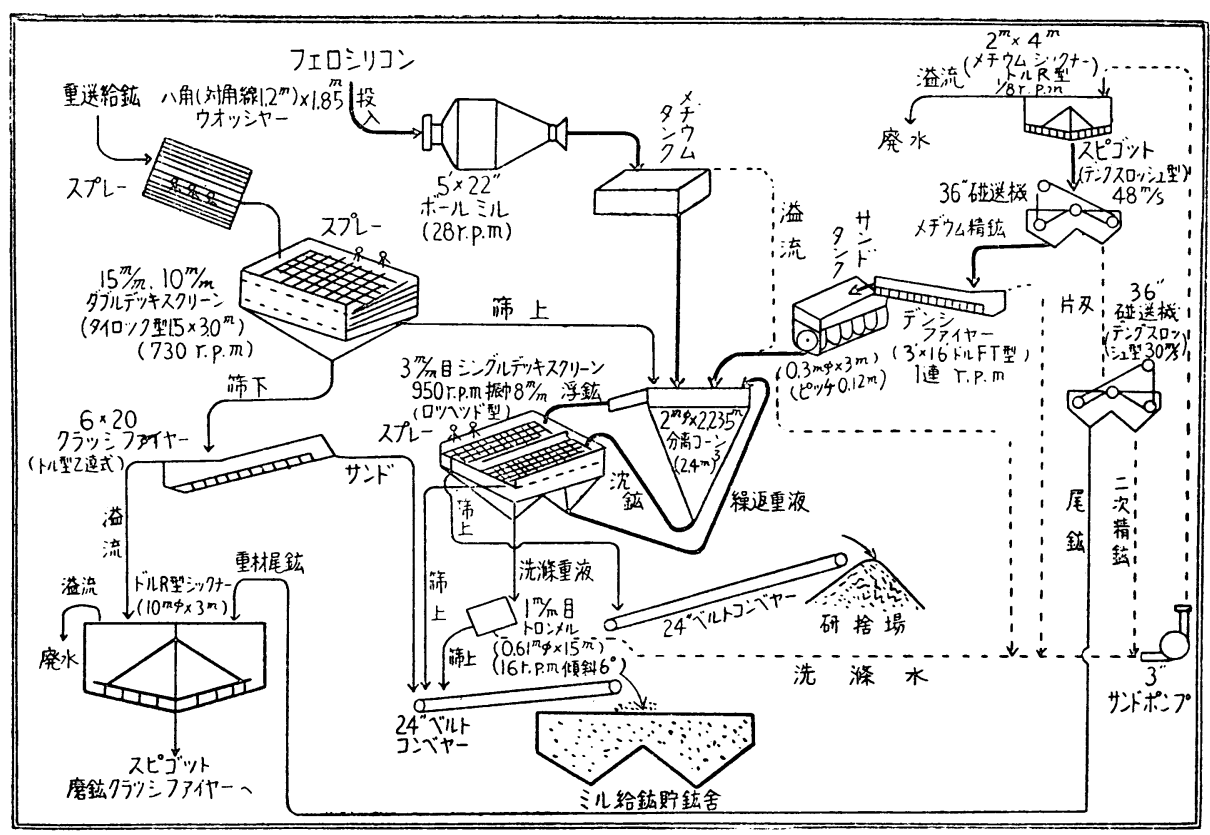

第9図重液選鉱系統及び重液材浄化回収系統図

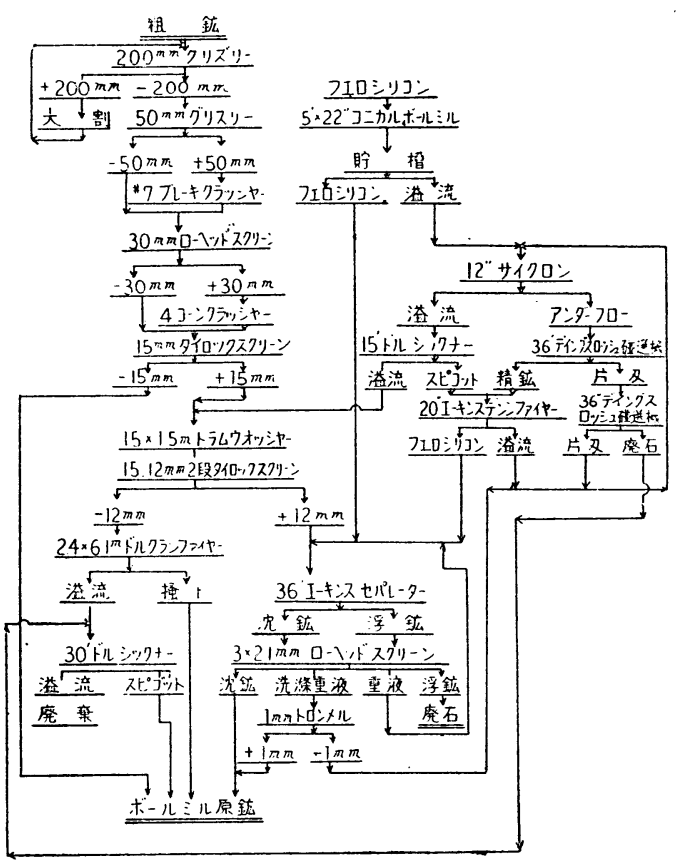

第10図 重液選釷系統図

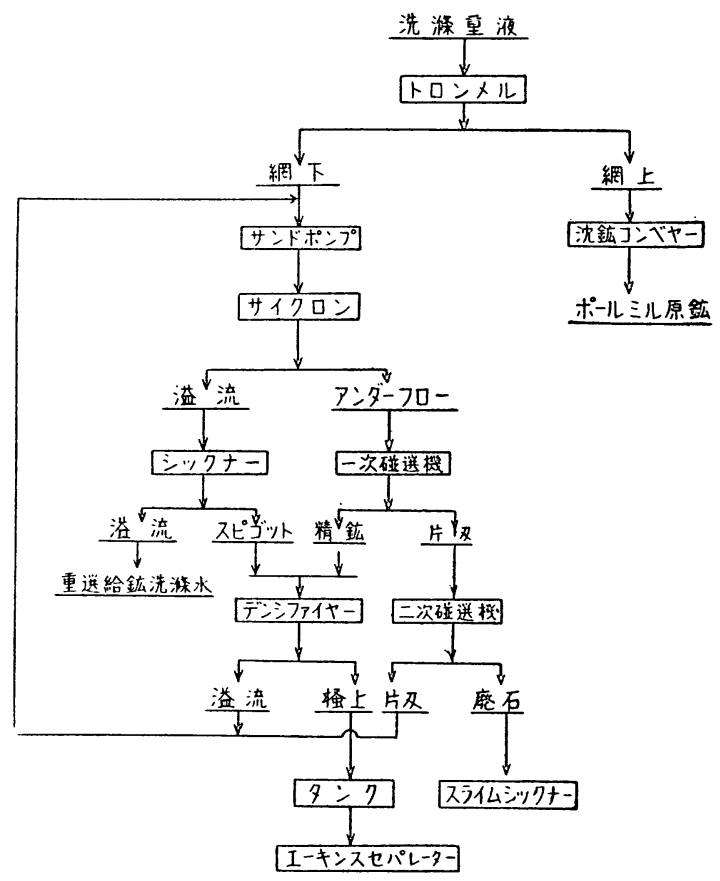

第11図 重液材の浄化回収系統図 
では循環重夜中のスライム量が $25 W_{t}+\%$ を超觉た際比 粘度 1.8 以上、分離比重 3.10 (重液規定比重 $3.00 \pm 0.02$ ) 分離精度 0.02 飞達した例がある。このため 現在比粘度 1.4 以下重液中のスライム量 $12 \%$ 以下にして操業する様 規定して分離精度を0.08以下にしている。

但し当所に括ける重液のスライムによる污濁程度は比
較的小で、現在のメジウム補給量と清浮回収系統で充分 重液の污濁を防止出来ると考光る。

\section{（1）現設備の欠陷の点及ひ今後成績向上のための対策} 等についての意見

(A) 日本鉱業白滝鉱業所

（1）スクリーン、ドラムウオッシャーの処理能力の関

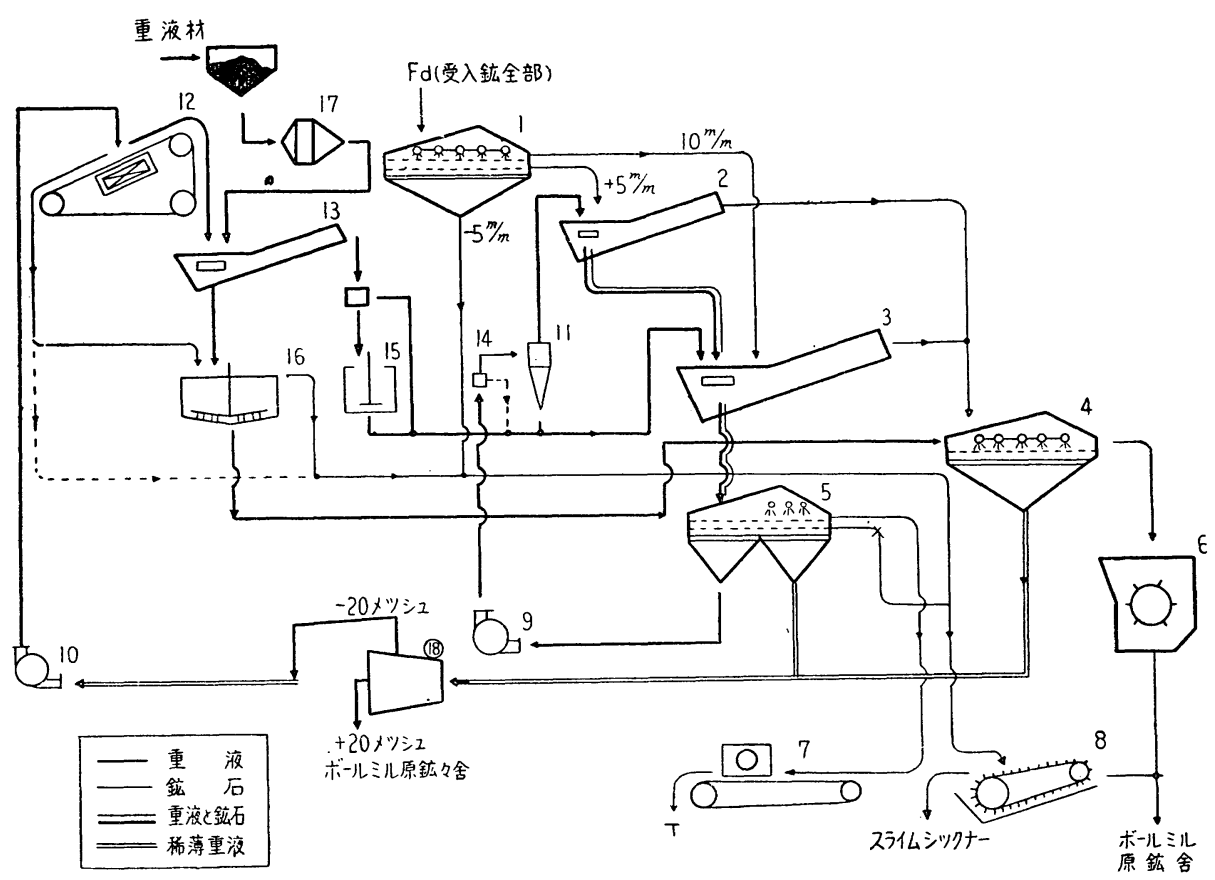

第 12 図䉆合森選鉱場重液選鉱系統図

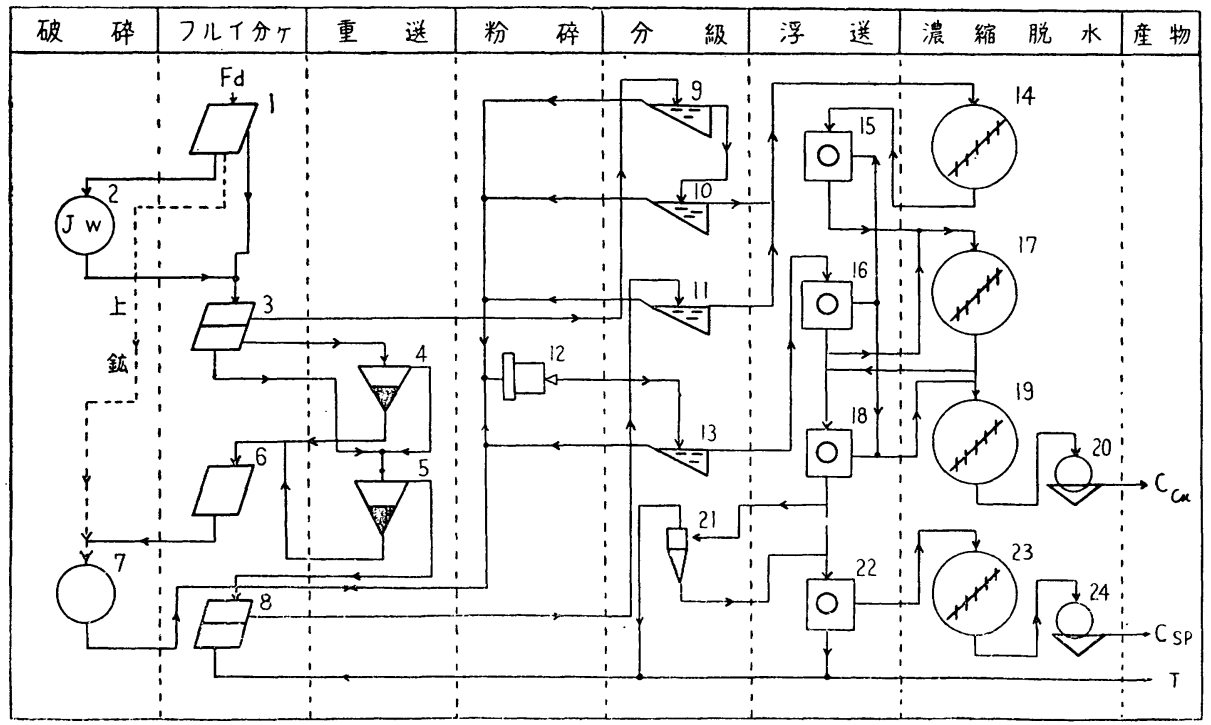

第 13 図鴜合森選鉱場系統図 


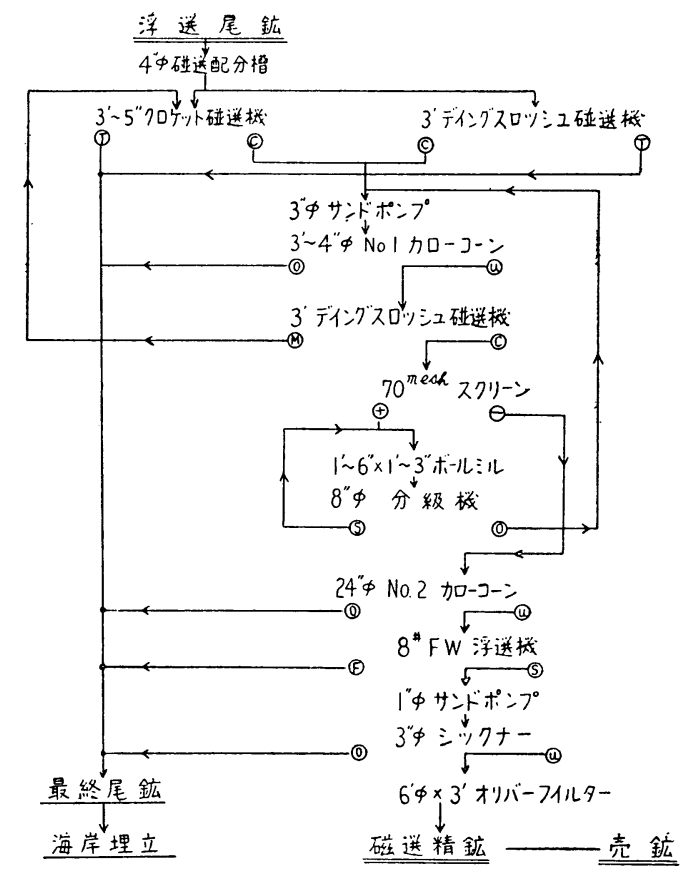

第14図 系 統 図

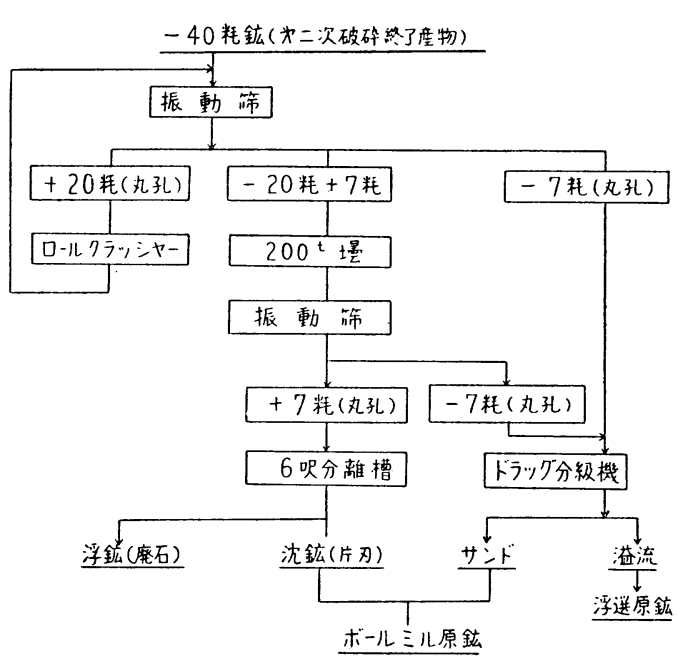

第15図 重 液 選 鉱系統図

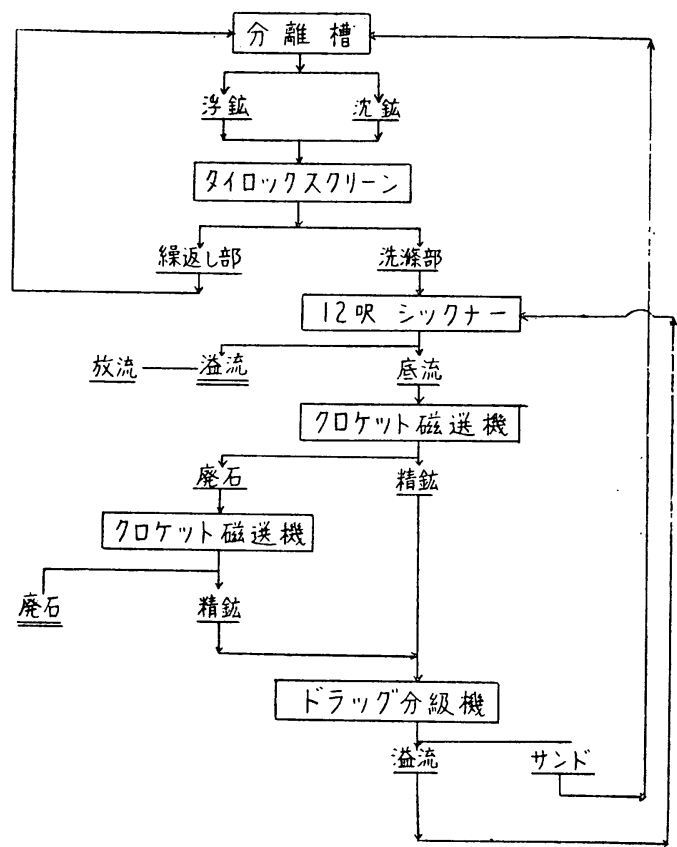

第16図 重液材の净化回収系統図

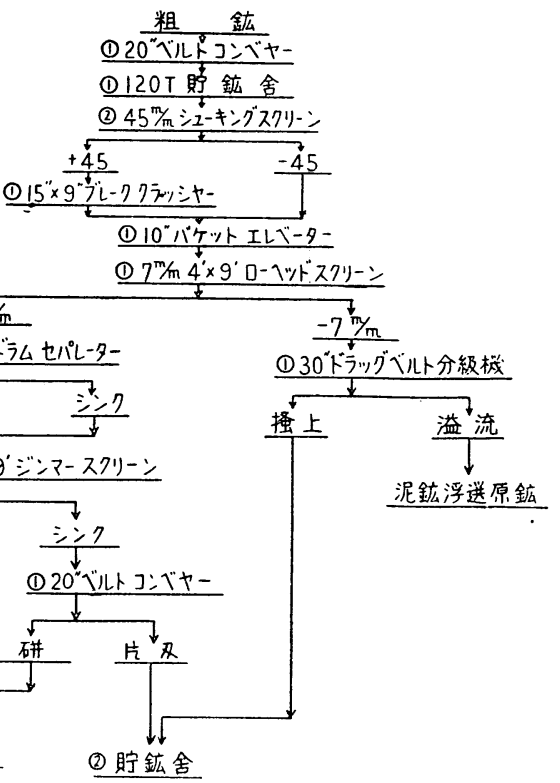

第17図 重液選鉱系統図 


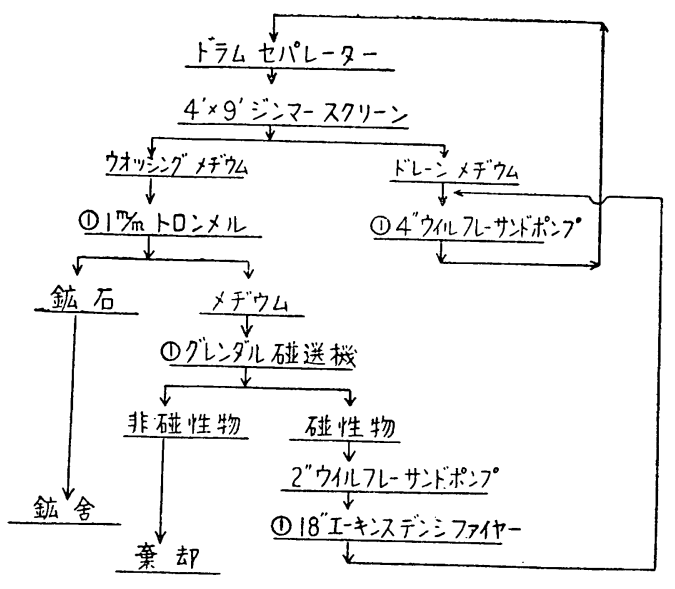

第18図 重液材の浄化回収系統図
係で原鉱の洗滌不足と磁選機の清掃不足が原因して分離 機中の非磁性物の含有が増加して高粘性となり分離効率 を低下するので月 1 回程度の分離機中のメヂウムの精選 を必要とする。

（2）比重調整のためデンシフアイヤーの变速装置を必 要としている。(3)給鉱粒度は現在 +8 m m $\sim 55 m / m$ としてい るが篩別効率不良が原因して細粒の重選分離が良くない ので粉鉱率の均一化節網目下限細度は検討を必要として いる。

\section{(B) 日本鉱業日立鉱業所}

（1）給鉱量の均一化を計る為ビンフイーダーの改造を 考党ている。

(2) 重液比重の 自仂測定記録計の 設置を検討中であ る。

第四表 重液選鉱成績比較表（含銅硫化分）

\begin{tabular}{|c|c|c|c|c|c|c|c|c|c|}
\hline \multirow{2}{*}{ 鉱山名 } & \multirow{2}{*}{ 鉱 種 } & \multicolumn{2}{|l|}{ 鉱 } & \multicolumn{2}{|l|}{ 品 } & \multirow{2}{*}{$\begin{array}{r}\text { 含 } \\
\mathrm{Cu}\end{array}$} & \multirow[t]{2}{*}{ 量 } & \multicolumn{2}{|c|}{ 採 収 率 } \\
\hline & & 屯 & $\%$ & $\mathrm{Cu} \%$ & $\mathrm{~S} \%$ & & & $\mathrm{Cu}$ & $\mathrm{S}$ \\
\hline \multirow{3}{*}{$\begin{array}{c}\text { 旦 } \\
\text { 鉱 } \\
\text { 滰 }\end{array}$} & 原 鉱 & 13,940 & 100.0 & 1.45 & 17.5 & $202^{t} 067$ & $2,436^{t} 372$ & 100 & 100 \\
\hline & 沈 鉱 & 6,544 & 47.0 & 2.93 & 35.5 & 191.731 & 2.312 .908 & 94.7 & 95.0 \\
\hline & 浮 鉱 & 7,396 & 53.0 & 0.14 & 1.7 & 10.336 & 123.464 & 5.3 & 5.0 \\
\hline \multirow{3}{*}{$\begin{array}{c}\text { 旦 } \\
\text { 鉄 } \\
\text { 是 } \\
\text { 立 }\end{array}$} & 原 鉱 & & 100.0 & 0.90 & 15.22 & & & 100.0 & 100.0 \\
\hline & 沈 鉱 & & 56.9 & 1.49 & 24.74 & & & 94.7 & 92.5 \\
\hline & 浮 鉱 & & 43.1 & 0.11 & 2.66 & & & 5.3 & 7.5 \\
\hline \multirow{3}{*}{$\begin{array}{l}\text { 集 } \\
\text { 稚 } \\
\text { 連 } \\
\end{array}$} & 原 鉱 & 30,694 & 100.0 & 1.86 & 20.01 & 5696541 & $6,140.541$ & 100.0 & 100.0 \\
\hline & 沈 鉱 & 19,981 & 65.1 & 2.76 & 29.54 & 552.081 & $5,901.497$ & 96.9 & 96.1 \\
\hline & 浮 鉱 & 10,713 & 34.9 & 0.16 & 2.23 & 17.460 & 238.908 & 3.1 & 3.9 \\
\hline \multirow{3}{*}{$\begin{array}{l}\text { 石 } \\
\text { 泉 } \\
\text { 州 }\end{array}$} & 原 鉱 & 32,769 & 100.0 & 0.71 & 6.44 & 233.3 & 2108 & 100.0 & 100.0 \\
\hline & 沈 鉱 & 13,861 & 42.3 & 1.46 & 12.28 & 201.9 & 1701 & 86.7 & 80.6 \\
\hline & 浮 鉱 & 18,908 & 57.7 & 0.05 & 2.15 & 9.4 & 407 & 4.0 & 19.4 \\
\hline \multirow{3}{*}{$\begin{array}{l}\text { 菱 } \\
\text { 妙 } \\
\text { 法 }\end{array}$} & 原 鉱 & $13,368.5$ & 100.0 & 0.93 & 6.63 & 124.2 & 885.7 & 100.0 & 100.0 \\
\hline & 沈 鉱 & $6,215.5$ & 46.6 & 1.92 & 12.39 & 119.5 & 770.4 & 96.3 & 87.2 \\
\hline & 浮 鉱 & 7,143 & 53.4 & 0.07 & 1.61 & 4.7 & 115.3 & 3.7 & 12.8 \\
\hline \multirow{3}{*}{ 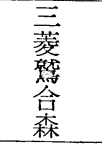 } & 原 鉱 & 4,824 & 100.0 & 1.68 & 3.81 & 81.266 & 183.991 & 100.0 & 100.0 \\
\hline & 沈 鉱 & 2,134 & 43.2 & 3.71 & 7.78 & 79.257 & 166.049 & 97.4 & 90.3 \\
\hline & 浮 鉱 & 2,690 & 56.8 & 0.07 & 0.67 & 2.009 & 17.942 & 2.6 & 9.7 \\
\hline \multirow{3}{*}{$\begin{array}{l}\text { 古 } \\
\text { 足 } \\
\text { 足 }\end{array}$} & 原 鉱 & 23,838 & 100.0 & 0.39 & & 940 & & 100.0 & \\
\hline & 沈 鉱 & 13,422 & 56.2 & 0.60 & & 803 & & 85.4 & \\
\hline & 浮 鉱 & 10,416 & 43.8 & 0.13 & & 137 & & 14.6 & \\
\hline \multirow{3}{*}{$\begin{array}{c}\text { 日 } \\
\text { 鉱 } \\
\text { 枋 } \\
\text { 木 }\end{array}$} & 原 鉱 & 1,707 & 100.0 & 1.25 & 3.73 & 21.270 & 63.617 & 100.00 & 100.00 \\
\hline & 沈 鉱 & 859 & 50.32 & 2.43 & 6.53 & 20.847 & 56.060 & 98.01 & 88.12 \\
\hline & 浮 鉱 & 772 & 45.23 & 0.05 & 0.90 & 392 & 6.951 & 1.85 & 10.93 \\
\hline
\end{tabular}


第五表重液選鉱機の種類並に仕様

\begin{tabular}{|c|c|c|c|c|c|c|c|c|}
\hline 摘 要 & $\begin{array}{ll}\text { 㒶 鉱 } \\
\text { 滝 }\end{array}$ & $\begin{array}{ll}\text { 日 } & \text { 鉱 } \\
\text { 日 } & \text { 立 }\end{array}$ & $\begin{array}{l}\text { 集 友 } \\
\text { 佐 }\end{array}$ & $\begin{array}{ll}\text { 石 } & \text { 原 } \\
\text { 紀 } & \text { 州 }\end{array}$ & $\begin{array}{ll}\text { 菱 } & \text { 菱 } \\
\text { 妙 }\end{array}$ & 恶会萎 & $\begin{array}{ll}\text { 趸 河 } & \text { 尾 }\end{array}$ & $\begin{array}{l}\text { 旦 } \\
\text { 榞 }\end{array}$ \\
\hline 型 & エーキンス型 & エーキンス型 & \begin{tabular}{|} 
ウエムコ \\
ドラム式 \\
シングル型
\end{tabular} & $\begin{array}{l}\text { 開項式 } \\
\text { コーシ型 }\end{array}$ & エーキンス & エーキンス & $\begin{array}{l}\text { コーン型 } \\
\text { 外部エ予 } \\
\text { リフト式 }\end{array}$ & $\mid \begin{array}{l}\text { ウエムゴ } \\
\text { シグルドラム } \\
\text { セパレーター }\end{array}$ \\
\hline $\begin{array}{l}\text { 台 } \\
\text { 数 }\end{array}$ & 1 & 1 & 1 & 1 & 1 & 2 & 1 & 1 \\
\hline $\begin{array}{l}x \\
1 \text { 力 }\end{array}$ & 栗本鉄工所 & 栗本鉄工所 & & 自 & 田原製作所 & 横山工業 & 自 & 住友機械工業 \\
\hline 犬 & $30^{\prime \prime} \phi$ & $\begin{array}{l}50 " \\
\text { スパイラル径 }\end{array}$ & $\begin{array}{l}\text { 直径 } 8^{\prime} \\
\text { 長さ } 6^{\prime}\end{array}$ & $\begin{array}{c}2000 \mathrm{~m} / \mathrm{m} \phi \\
2235 \mathrm{~m} / \mathrm{m} \\
\text { 容量 } 2.4 \mathrm{~m}^{3}\end{array}$ & $\begin{array}{c}1.0 \times 4.8 \mathrm{~m} \\
\text { スパイラル径 } \\
900 \mathrm{~m} / \mathrm{m}\end{array}$ & $\begin{array}{l}30^{\prime \prime} \times 16^{\prime}, 1 \text { 台 } \\
30^{\prime \prime} \times 13^{\prime} 1 \text { 台 } \\
\end{array}$ & $\begin{array}{l}1830 \mathrm{~m} / \phi \\
1830 \mathrm{~m} / \mathrm{m}\end{array}$ & $6^{\prime \prime} \times 4^{\prime}$ \\
\hline $\begin{array}{l}\text { 能力 } \\
\mathrm{T} / \mathbf{H} \mathbf{r}\end{array}$ & 27 & 80 & 80 & $45 \sim 50$ & 50 & 各23 & 30 & 15 \\
\hline $\begin{array}{l}\text { 其 } \\
\text { 他 }\end{array}$ & 8r. p.m. & $\begin{array}{l}\text { 周速 } \\
23.9 \mathrm{~m} / \mathrm{min}\end{array}$ & $\begin{array}{l}7.5 \mathrm{HP} \\
0.75 \sim 3.0 \\
\mathrm{rpm} \text { 可変 }\end{array}$ & & & & & \\
\hline
\end{tabular}

(3) クロケツト磁選機は老栝しているので取替を計画 している。

\section{(C) 住友佐々連鉱叢所}

（1）出鉱粗釷の品位上昇と粗鉱中のガリ鉱 (片刃状鉱) 量の増大のため重液比重士 0.10 の鉱量分布が大となり分 離効果を悪くするとともと浮鉱品位を高める原因となつ てこの対策腐心している。

（2）各重液比重值とついて比粘度とスライム湜入率の 関係線は実験作成しているが、高比重㲘濁液の粘度を出 来るだけ正確に且、容易飞現場にて使用可能な器具の作 成努力している。

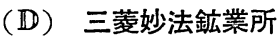

(1) 湿泥釷石処理とその改善

坑内一部より産出する湿泥状鉱石は処理量が低下する 上、節別洗湺が不充分で重選に悪影響を及ぼす。又本鉱 中の重選給鉱対象鉱には品位高く而も比重の比較的小さ い鉱粒が多いから、他の鉱石と同一条件では、浮鉱品位 上昇の原因となる。これらの点より本鉱に対する洗條の 強化或は重選より除去等飞つき検討したい。

(2) 重液比重計の設置

現在人手で毎時測定しているが、給鉱の鉱量、品位サ イズの変動に対処して操業条件を調節するには不充分で あるから連続指示式比重計を設置したい。

(3) 二次磁選機操業方法の改善

現在重液材損失の最む多いのは二次磁選機である。こ れは同給鉱の水量が多いからで、より適切な給鉱方法、 ベルト速度等を検討したい。

（4）細粒鉱に対する重選実施
現在の重選給鉱サイズ下限以下で $3 \sim 5 m$ 以上の部分 （粗釷の $25 \%$ ）は重選可能であるから別途処理につき検 討中である。

\section{(5) 重液材の検討}

コスト低減の目的で、重液材として磁鉄鉱を使用すべ く試験中である。

\section{$(\mathbb{E})$ 三菱丳合森鉱業所}

磁選機給鉱をサンドポンプより直接給釷しているので 水量が多く磁選機の実収す思い様と思われるのでシック ナーで 1 度濃縮後磁選処理すれば回収率も向上するので はないかと思われる。而し当方では現設備の配置上已む を得ず現在の系統にしているが逐次 $\mathrm{Fe}-\mathrm{Si}$ の使用を中 止硫化鉄飞切替中である。将来この点解消出来るむのと 思われる。

\section{（F）日本鉱業杤不鉱業所}

現在特に重大な欠陷ではないがローヘッドスクリーン 及ジンマースクリーンの目詰りが考光られる。ローヘツ ドスクリーン $(7 \mathrm{~m} / \mathrm{m})$ の目詰りにより概して細粒がドラ ムセバレーターに大り浮鉱中或は沈鉱中に迷い込むもの がある。

又ジンマースクーンに於てはメヂウム落下部の目詰り によりドレーンメデウムの 1 部が 水洗メヂウムに入る （1 部）ので重液材損失の原因となる。

以上スクリーンの目詰り防止施策を考究すると共に回 収系統の 1 部整備を必要とする。 
第六表磁力選鉱 機

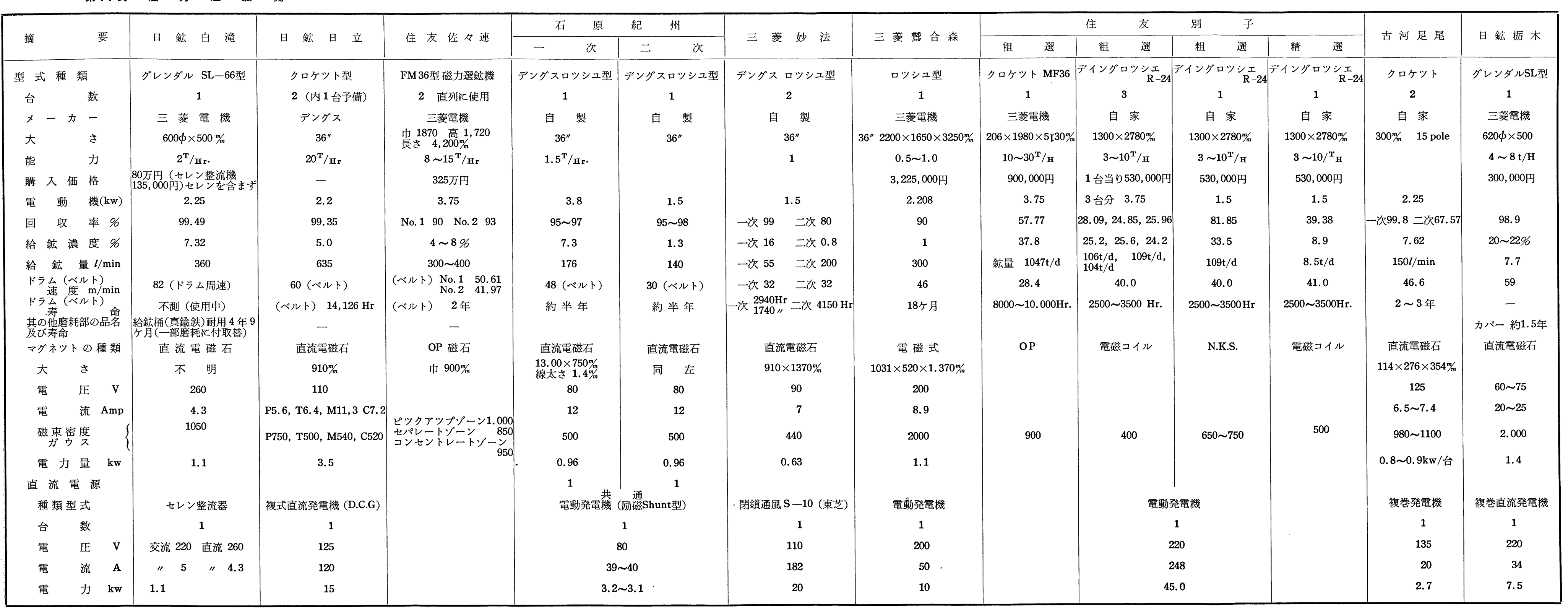

$-50-$ 
第七表重液材及ひその消費量

\begin{tabular}{|c|c|c|c|c|c|c|c|c|}
\hline 要 & 日鉱白潼 & 日鉱 日立 & 住友作々連 & 石 原 紀 州 & 三蒦妙法 & 三菱知合森 & 古 河 足 尾 & 日鉱杤木 \\
\hline 重 液 材 & & & & & & & & \\
\hline 種類 & フエロシリコン & フエロシリコン & フエロシリコン & 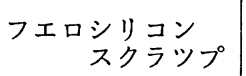 & フエロシリコン & フエロシリコン & フエロシリコン & 砂 鉄 \\
\hline X - カ - & 竹内工業 & 生野製煉所 & 不 定 & & 生野製作所 & 生野鉣業所 & 日本カーリット渋川 & 桑正株式会社 \\
\hline 購 入 価 格 & & $26,000.00$ & $30,000 \sim 40,000$ 円 & 40,000円 & $28,000 円$ & 25,000 円 & 22,000 円 & $\begin{array}{r}3800 \\
+65 \quad 3.1 \%\end{array}$ \\
\hline 購入畤の粒度 & $\begin{array}{lrl}+48 & 2.95 \% & \pm 1.5 \\
-200 & 60 \% & \pm 0.50\end{array}$ & $400 \sim 20 m / m$ & $150 \sim 200^{m / m}$ & $\begin{array}{l}\text { スクラップの } \\
\text { 委亲の塊状 }\end{array}$ & $20 \sim 500^{m / m}$ & $30 \sim 50 m$ & $-80 \%$ & $\begin{array}{rr}+100 & 15.4 \% \\
+200 & 76.5 \% \\
-200 & 5.0 \%\end{array}$ \\
\hline $\begin{array}{l}\text { 化学成分表 \% } \\
\text { 其他判明せ方成分 \% }\end{array}$ & Fe 82.38 Si 15.40 & $\begin{array}{cc}\mathrm{Fe} & 76.19 \\
\mathrm{Si} & 16.53 \\
\mathrm{C} & 0.44\end{array}$ & 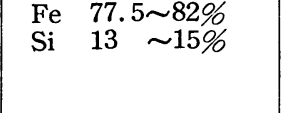 & $\begin{array}{ll}\mathrm{Fe} & 80.50 \\
\mathrm{Si} & 16.04 \\
\text { 其他 } & 3.46\end{array}$ & $\begin{array}{ll}\text { Fe } & 78 \\
\text { Si } & 16 \\
\text { Sn } & 1.5\end{array}$ & $\begin{array}{l}\mathrm{Fe} \\
\mathrm{Si}\end{array}$ & $\begin{array}{ll}\text { Fe } & 75.90 \% \\
\text { Si } & 17.410 \\
\text { Pl } & 1.07\end{array}$ & 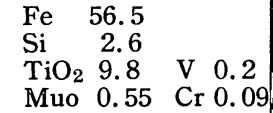 \\
\hline 重 & 6.61 (フエロシリコン) & 6.62 & $6.35 \sim 6.7$ & $6.46 \sim 6.50$ & 6.63 & 6.19 & 6.42 & 4.72 \\
\hline 分離機内重液 & 5.54 & & & & & & & \\
\hline 磁性物の含有量 & (フ8 6\% & 98.5 & $98 \sim 99$ & $99.3 \sim 98.8$ & 99.81 & $98 \%$ & $98.8 \%$ & 96.1 \\
\hline 硬度ロックウエル & & 47 & & & 68.4 & & 44.5 & \\
\hline 重液村迄の粉碎方法 & チユーブミル中にて & 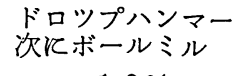 & ブレーキクラシシシャー & 芷ールミル湿式 & ボールミル湿式 & ボールミル湿式粉碎 & ボールミル湿式粉䂶 & ボールミル湿式枌础 \\
\hline & $\begin{array}{cc}+65 & 13.3 \% \\
+100 & 9.10\end{array}$ & $\begin{array}{l}1.9 \% \\
7.7 \%\end{array}$ & 0 & 0 & 1.6 & $\begin{array}{l}7.12 \% \\
408\end{array}$ & - & $0.3 \%$ \\
\hline 重液村の節別分析 & $\begin{array}{ll}+150 & 8.10\end{array}$ & $10.7 \%$ & - & $\begin{array}{l}8.0 \\
-\end{array}$ & $\begin{array}{l}4.6 \\
-\end{array}$ & $\begin{array}{l}4.08 \\
-\end{array}$ & 0 & $\begin{array}{r}11.9 \\
-\end{array}$ \\
\hline & $+200 \quad 12.50$ & $20.4 \%$ & 30.55 & 43.0 & 26.8 & 14.78 & $10.1 \%$ & 67.6 \\
\hline & $-200 \quad 57.0$ & $59.3 \%$ & 69.45 & 49.0 & 67.0 & 74.02 & $89.9 \%$ & 20.2 \\
\hline 消費量 $\mathrm{g} / \mathrm{t}$ & & & & & & & & \\
\hline 浮鉣附着損失 & 29 & 27 & 19.2 & 54.5 & 4.0 & 21 & 58 & 47 \\
\hline 沈鉱 " & 42 & 44 & 32.8 & 36.5 & 3.8 & 21 & 59 & 23 \\
\hline 回収系統の損失 & 256 & 176 & 250 & 227 & 92.2 & 378 & 143 & 572 \\
\hline 取扱損失 其 他 & 25 & 5 & 250 & 182 & 不 明 & 30 & 不詳 & 288 \\
\hline 計 & 352 & 252 & 302 & 500 & 430 & 450 & 260 & 930 \\
\hline
\end{tabular}

$-51-$ 
第八表 重液選鉱成績比較表

\begin{tabular}{|c|c|c|c|c|c|c|c|c|c|c|c|c|c|c|c|c|c|c|}
\hline \multirow{2}{*}{\multicolumn{2}{|c|}{ 鉣山名 }} & \multirow{2}{*}{ 鉱 種 } & \multicolumn{2}{|l|}{ 鉱 } & \multicolumn{4}{|c|}{ 品 } & \multicolumn{3}{|c|}{ 位 } & \multicolumn{4}{|c|}{ 埰 } & \multicolumn{3}{|c|}{ 摔（\%) } \\
\hline & & & $\mathrm{T}$ & $\%$ & $\%$ & & $\mathrm{Cu}$ & $\mathrm{S}$ & $\mathrm{Fe}$ & $\mathrm{Pb}$ & $\mathrm{Zn}$ & & & $\mathrm{Cu}$ & $\mathrm{S}$ & $\mathrm{Fe}$ & $\mathrm{Pb}$ & $\mathrm{Zn}$ \\
\hline & & \begin{tabular}{|cc} 
給 & 鉱 \\
浮 & 鉱 \\
沈 & 鉱
\end{tabular} & $\begin{array}{r}2,130 \\
1,143 \\
987\end{array}$ & $\begin{array}{r}100.0 \\
53.7 \\
46.3\end{array}$ & $\begin{array}{c}\mathrm{WO}_{3} \\
0.35 \\
0.07 \\
0.67\end{array}$ & & & & & & & $\begin{array}{r}\mathrm{WO}_{3} \\
100.0 \\
10.8 \\
89.2\end{array}$ & & & & & & \\
\hline & $\begin{array}{l}\text { 庄 } \\
\text { 石 }\end{array}$ & $\begin{array}{ll}\text { 給 } & \text { 鉱 } \\
\text { 沈 } & \text { 鉱 } \\
\text { 浮、鉱 }\end{array}$ & $\begin{array}{l}6,546 \\
5.233 \\
1,313\end{array}$ & $\begin{array}{r}1000.0 \\
80.0 \\
20.0\end{array}$ & $\begin{array}{c}\mathrm{Mn} \\
32.21 \\
37.17 \\
12.45\end{array}$ & $\begin{array}{l}\mathrm{SiO}_{2} \\
21.16 \\
11.79 \\
58.51\end{array}$ & & & & & & $\begin{array}{l}\text { Mn } \\
100.0 \\
92.25 \\
7.75\end{array}$ & $\begin{array}{r}\mathrm{SiO}_{2} \\
100.0 \\
44.53 \\
55.47\end{array}$ & & $!$ & . & & \\
\hline & & $\begin{array}{cc}\text { 粗 } & \text { 鉱 } \\
\text { 浮 } & \text { 鉱 } \\
\text { 沈 } & \text { 鉱 }\end{array}$ & $\begin{array}{r}8,903 \\
2.249 \\
6,654\end{array}$ & $\begin{array}{c}100.0 \\
25.26 \\
74.74\end{array}$ & & & & $\begin{array}{r}13.73 \\
\cdot 1.48 \\
17.88\end{array}$ & \begin{tabular}{|r|}
18.26 \\
8.50 \\
21.55
\end{tabular} & $\begin{array}{l}5.56 \\
0.28 \\
7.35\end{array}$ & $\begin{array}{r}7.98 \\
0.94 \\
10.36\end{array}$ & & & & $\left|\begin{array}{r}100.0 \\
2.73 \\
97.27\end{array}\right|$ & $\begin{array}{l}100.0 \\
11.76 \\
88.24\end{array}$ & $\begin{array}{r}100.0 \\
1.25 \\
98.75\end{array}$ & \begin{tabular}{|r|r|}
100.0 \\
$2.9 \varepsilon$ \\
97.02
\end{tabular} \\
\hline & $\begin{array}{l}\text { 洋 } \\
\text { 立 }\end{array}$ & $\begin{array}{cc}\text { 原 } & \text { 鉱 } \\
\text { 沈 } & \text { 鉱 } \\
\text { 浮 } & \text { 鉱 }\end{array}$ & $\begin{array}{l}3,131.6 \\
1,741.3 \\
1,390.3\end{array}$ & $\begin{array}{r}100.0 \\
55.6 \\
44.4\end{array}$ & $\begin{array}{l}\text { Sn } \\
2.37 \\
4.00 \\
0.30\end{array}$ & & & & & & & \begin{tabular}{r}
\multicolumn{1}{c}{$\mathrm{Sn}$} \\
100.0 \\
94.4 \\
5.6
\end{tabular} & & & & & & $!$ \\
\hline & & $\begin{array}{cc}\text { 原 } & \text { 鉱 } \\
\text { 沈 } & \text { 鉱 } \\
\text { 浮 } & \text { 鉱 }\end{array}$ & $\left|\begin{array}{r}14,426 \\
10,800 \\
3,625\end{array}\right|$ & $\begin{array}{c}100.0 \\
74.78 \\
25.13\end{array}$ & & & $\begin{array}{l}0.74 \\
0.96 \\
0.09\end{array}$ & $\begin{array}{r}20.25 \\
26.20 \\
2.53\end{array}$ & $\begin{array}{r}31.35 \\
39.24 \\
8.50\end{array}$ & & & & & $\begin{array}{r}100.0 \\
90.80 \\
3.20\end{array}$ & $\left|\begin{array}{r}100.0 \\
93.86 \\
3.14\end{array}\right|$ & $\begin{array}{r}100.0 \\
93.22 \\
6.78\end{array}$ & & \\
\hline $\begin{array}{l}\text { 同 } \\
\text { 和 } \\
\text { 椆 } \\
\text { 原 }\end{array}$ & $\begin{array}{l}\text { 機 } \\
\text { 械 } \\
\text { 粉 } \\
\text { 采 } \\
\text { 角 } \\
\end{array}$ & $\begin{array}{ll}\text { 原 } & \text { 鉱 } \\
\text { 精 } & \text { 鉱 } \\
\text { 磁硫鉄 } \\
\text { 精 } & \text {. 鉱 }\end{array}$ & $\begin{array}{l}. \\
\vdots\end{array}$ & $\begin{array}{r}100.0 \\
95.0 \\
5.0\end{array}$ & & & $\begin{array}{l}0.31 \\
0.30 \\
0.41\end{array}$ & $\begin{array}{l}46.32 \\
46.80 \\
37.10\end{array}$ & $\begin{array}{l}43.25 \\
42.86 \\
53.30\end{array}$ & & . & & & $\begin{array}{r}100.0 \\
93.2 \\
6.8 \\
\end{array}$ & \begin{tabular}{|r|}
100.0 \\
96.0 \\
4.0 \\
\end{tabular} & $\begin{array}{r}100.0 \\
94.2 \\
5.8\end{array}$ & & \\
\hline $\begin{array}{l}\text { 磁 } \\
\text { 選 } \\
\text { 成 } \\
\text { 績 }\end{array}$ & $\begin{array}{l}\text { 筫 } \\
\text { 粉 } \\
\text { 䋅 } \\
\text { 筩 }\end{array}$ & $\begin{array}{ll}\text { 原 } & \text { 鉱 } \\
\text { 精 } & \text { 鉱 } \\
\text { 磁硫鉱 } \\
\text { 精 } & \text { 鉱 }\end{array}$ & . & $\begin{array}{r}100.0 \\
95.8 \\
4.2\end{array}$ & & & $\begin{array}{l}0.31 \\
0.31 \\
0.44\end{array}$ & $\begin{array}{l}46.43 \\
46.77 \\
38.64\end{array}$ & $\begin{array}{l}43.14 \\
42.87 \\
49.24\end{array}$ & & & i & & $\begin{array}{r}100.0 \\
95.3 \\
4.7 \\
\end{array}$ & \begin{tabular}{|r|}
100.0 \\
95.5 \\
3.5
\end{tabular} & $\begin{array}{r}100.0 \\
95.2 \\
4.8\end{array}$ & & \\
\hline & & $\begin{array}{cc}\text { 原 } & \text { 鉱 } \\
\text { 精 } & \text { 鉱 } \\
\text { 尾 } & \text { 鉱 }\end{array}$ & $\begin{array}{l}27,165 \\
12,607 \\
14,558\end{array}$ & $\begin{array}{r}100.0 \\
46.4 \\
53.6\end{array}$ & & & \begin{tabular}{l|}
1.08 \\
2.23 \\
0.08
\end{tabular} & $\begin{array}{l}4.90 \\
9.07 \\
1.31\end{array}$ & & $\begin{array}{l}0.23 \\
0.49 \\
0.01\end{array}$ & $\begin{array}{l}1.13 \\
2.31 \\
0.11\end{array}$ & & & $\begin{array}{r}100.0 \\
95.97 \\
4.03\end{array}$ & $\left|\begin{array}{l}100.0 \\
85.73 \\
14.27\end{array}\right|$ & & $\begin{array}{r}100.0 \\
98.86 \\
1.14\end{array}$ & $\begin{array}{r}100.0 \\
94.76 \\
\quad 5.24\end{array}$ \\
\hline $\begin{array}{l}\text { ラ } \\
\text { サ }\end{array}$ & $\begin{array}{l}\text { 鉛 } \\
\text { 带 } \\
\text { 鉛 } \\
\text { 系 }\end{array}$ & $\begin{array}{ll}\text { 原 } & \text { 鉱 } \\
\text { 沈 } & \text { 鉱 } \\
\text { 浮 } & \text { 鉱 }\end{array}$ & $\begin{array}{l}6,616 \\
4,572 \\
2,044\end{array}$ & $\begin{array}{r}100.0 \\
69.1 \\
30.9\end{array}$ & & & $\begin{array}{l}0.19 \\
0.23 \\
0.09\end{array}$ & $\begin{array}{r}14.51 \\
19.67 \\
4.17\end{array}$ & & $\begin{array}{l}1.67 \\
2.39 \\
0.19\end{array}$ & $\begin{array}{l}5.55^{\prime} \\
7.93^{\prime} \\
0.70^{\prime}\end{array}$ & & & $\left|\begin{array}{c|}100.0 \\
83.81 \\
16.16\end{array}\right|$ & $\left|\begin{array}{r}100.0 \\
92.39 \\
7.61\end{array}\right|$ & & $\left|\begin{array}{r}100.0 \\
95.44 \\
4.56\end{array}\right|$ & $\begin{array}{r}100.0 \\
95.92 \\
4.08\end{array}$ \\
\hline $\begin{array}{l}\text { 田 } \\
\text { 老 }\end{array}$ & $\begin{array}{l}\text { 含 } \\
\text { 銅 } \\
\text { 硫 } \\
\text { 华 } \\
\text { 系 }\end{array}$ & \begin{tabular}{ll|} 
原 & 鉱 \\
沈 & 鉱 \\
浮 & 鉱
\end{tabular} & $\begin{array}{r}13,494 \\
8,670 \\
4,824\end{array}$ & $\begin{array}{r}100.0 \\
64.3 \\
35.7\end{array}$ & & & $\begin{array}{l}0.57 \\
0.81 \\
0.10\end{array}$ & $\begin{array}{r}16.42 \\
23.31 \\
4.23\end{array}$ & & & & & & $\left|\begin{array}{r}100.0 \\
93.69 \\
6.31\end{array}\right|$ & $\left|\begin{array}{r}100.0 \\
90.69 \\
9.31\end{array}\right|$ & & & \\
\hline
\end{tabular}




\section{III 其}

他

\section{（1）重液選鉱系統図}

(A) 粟村鉱業大谷鉱山 第十九図 第二十図

(B) 鉄興社稲倉石鉱業所 第二十一図 第二十二図

(C) 東邦亚鉛対州鉱業所 第二十三図 第二十四図 第二十五図 第二十六図

（D） 東洋鉱山見立鉱業所 第二十七図 第二十八図

（E）日本鉱業河山鉱業所 第二十九図

（F）同和鉱業棚原鉱業所 第三十図

（G）日鉄鉱業釜石鉱業所 第三十一図

(H) 日本鉱業尾小屋鉱業所 第三十二図、第三十三 図

（I） ラサ鉱業田老鉱業所 第三十四図、第三十五図 第三十六図、第三十七図

（2）重液選鉱成績（32年 4 月～6 月実績）

第八表

\section{（3）重液選鉱機の種類並に仕様 第九表}

（4）磁力選鉱機 第十表

（5）重液材及びその消費量 第十一表

（6）重液の粘度と安定度について及ひ粘度と分離効果 との関係等についての考察

\section{(A) 鉄興社稲倉石鉱業所}

之と将来計画に関連し当所は比重上鉱 3.15 並鉱 $3.10 て ゙$ の操業なれば浮鉱品位が.上昇する傾向にあり今二次重選 計画中につき計画図を添附する。（第22図）

（B）東洋鉱山見立鉱業所メヂウムのサイズを粗くし た場合、分離槽内で、上下の比重差が現れ、甚だしい場 合、分離槽内に沈澱堆積を生じ易い。この為特にメヂウ

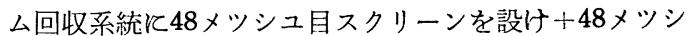
ユは除去している。

運転開始から終了までの間に於ける重液比重の安定は 粘度とはさして関係がないと考えられ、重液の安定性で は、フルバックでは重液の粘度は分離効にさしたる影響 を与えないだろうと頭初思考されたが、この考えは根本 的飞誤りであつた。即ち粘性が上昇すれば細粒中のメタ ルロスが増加するばかりでなく、ドレイネイヂゾーンで のメヂウムの回収が困難となり、従つて分離槽内重液比 重低下を招来する。

（C）日本鉱業河山鉱業所

粘度が高ければ安定し、低ければ不安定となるが、又 メヂアのサイズが細い場合安定し、粗い場合不安定とな る。安定度の良いことは望ましいが、粘度が高ければ分 離效率が低下するし、メヂアサイズが細い場合は酸化あ るいは回収系統炕よるオーベーフロ損失が多く、従つ てこの相反する条件を満足させる粘度サイズが問題とな
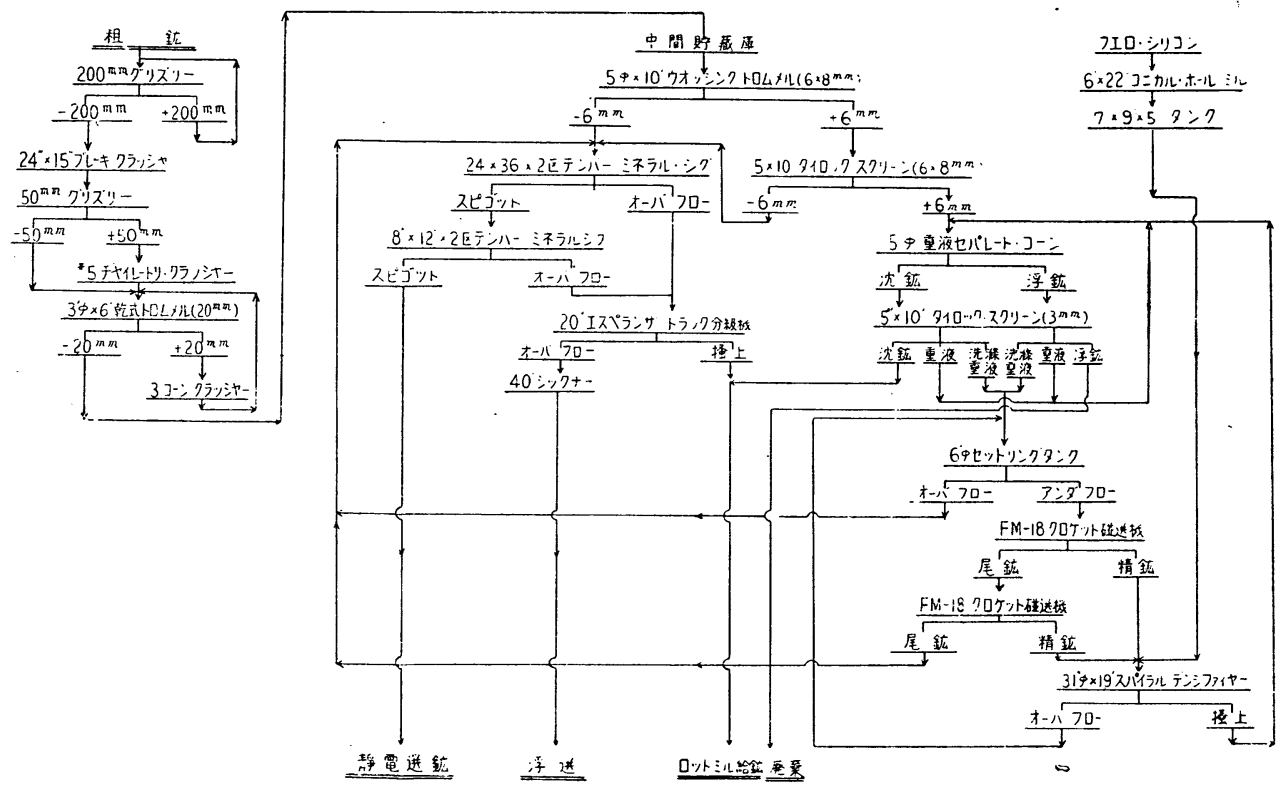

第 19 図重液選鉱系統図 

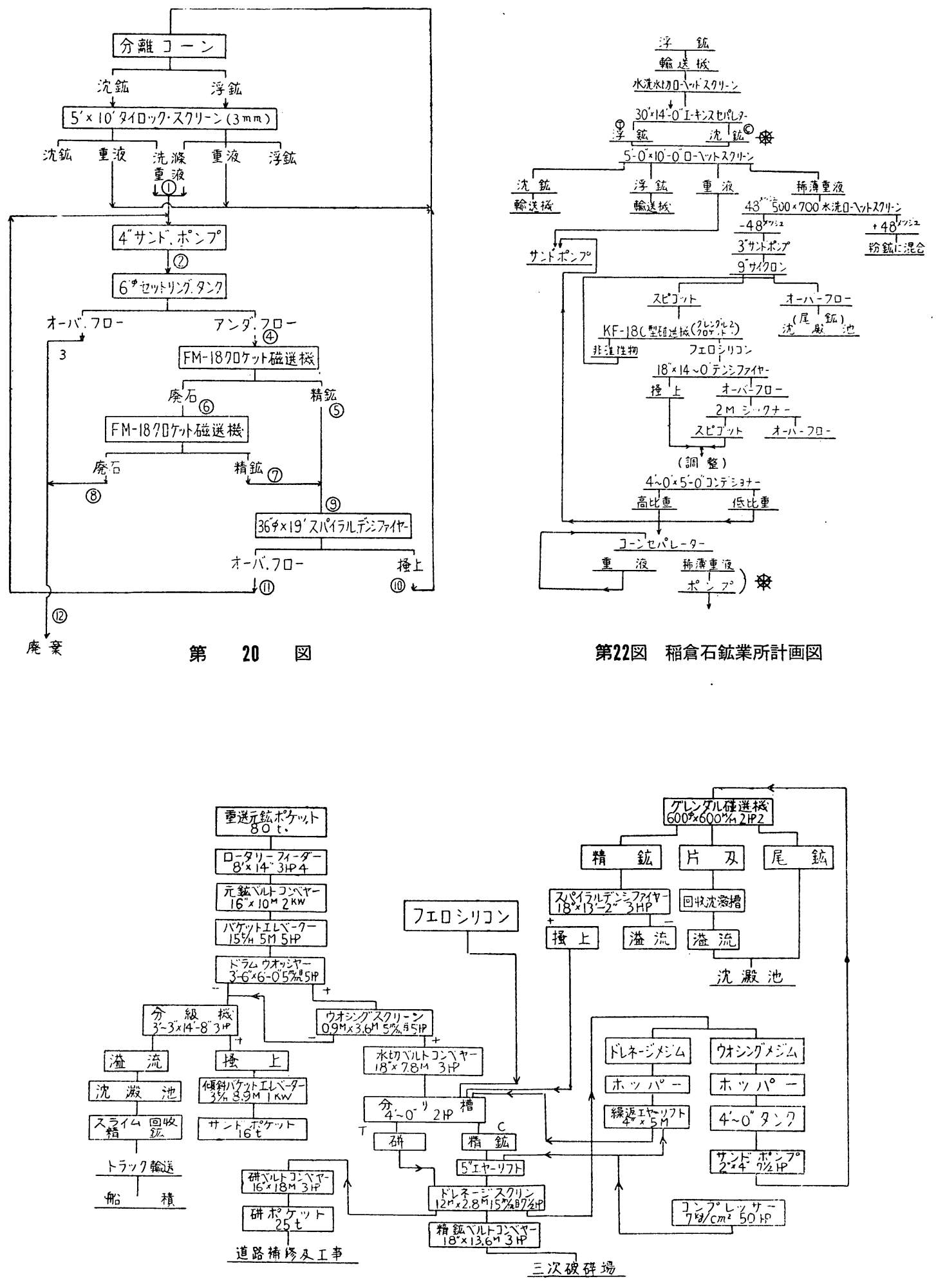

第 21 図稲倉石鉱業所重夜選鉱系統図 
註)

Screen Analysis of ferrosilicon

$$
\begin{array}{lr}
+65 \mathrm{M} & \mathrm{O} \\
+100 \mathrm{M} & 1.064 \% \\
+150 \mathrm{M} & 2.926 \% \\
+200 \mathrm{M} & 12.500 \% \\
+325 \mathrm{M} & 36.170 \% \\
-325 \mathrm{M} & 47.340 \%
\end{array}
$$

重液の比重 2.75

-325Mの kaoliniteをblendす

Kaolinite (wt $\%)$
A …... \% $\%$
B …...1.91\%
C......3.82\%
D......7.62\%

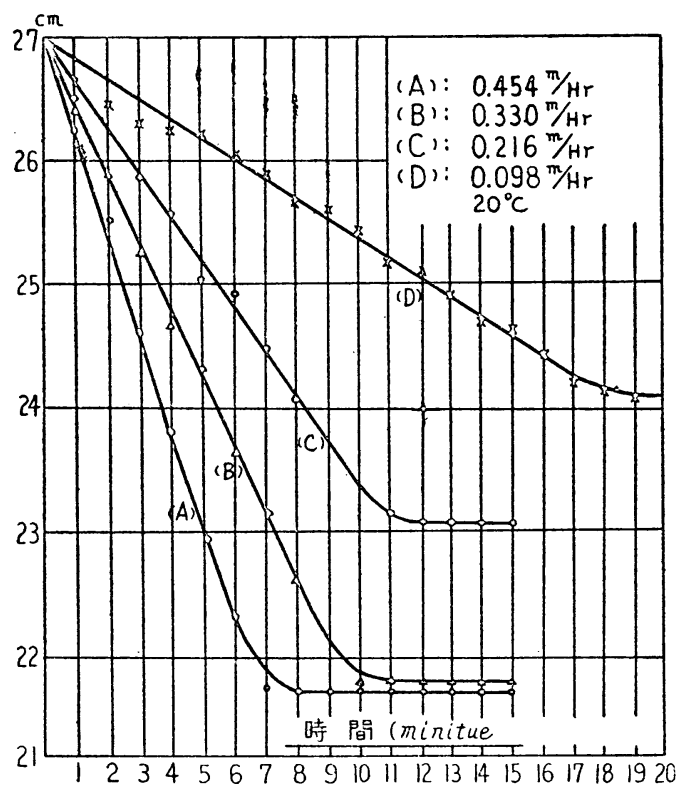

第2依 重液粘度とメデイアの沈降速度との関係

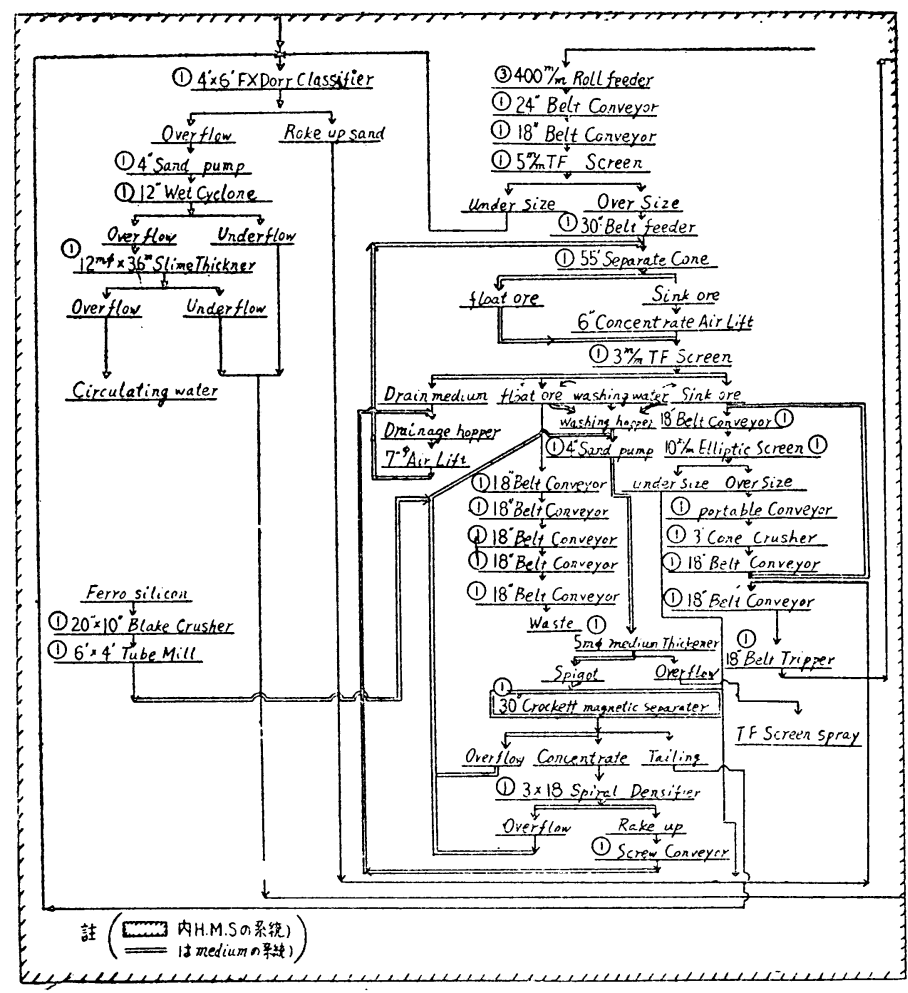

第 23 図

註)

重液の安定度算定として kaolinite $0 \%$ 場

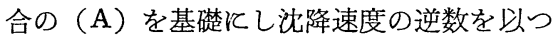
て表はす

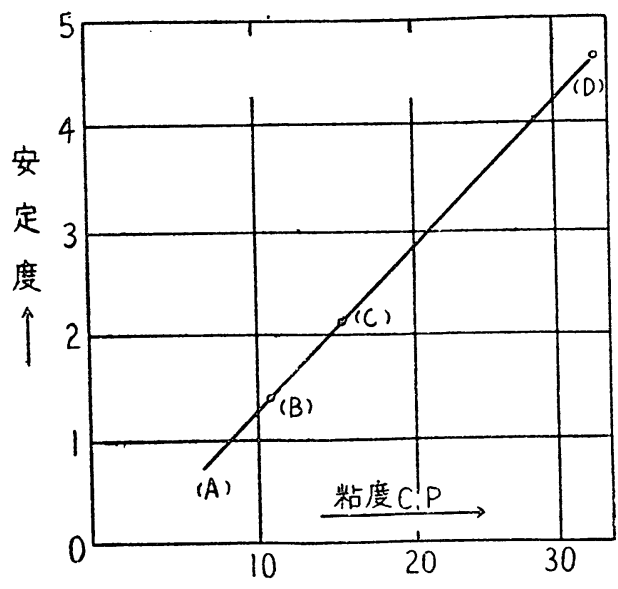

第25図 重液粘度と安定度との関係 

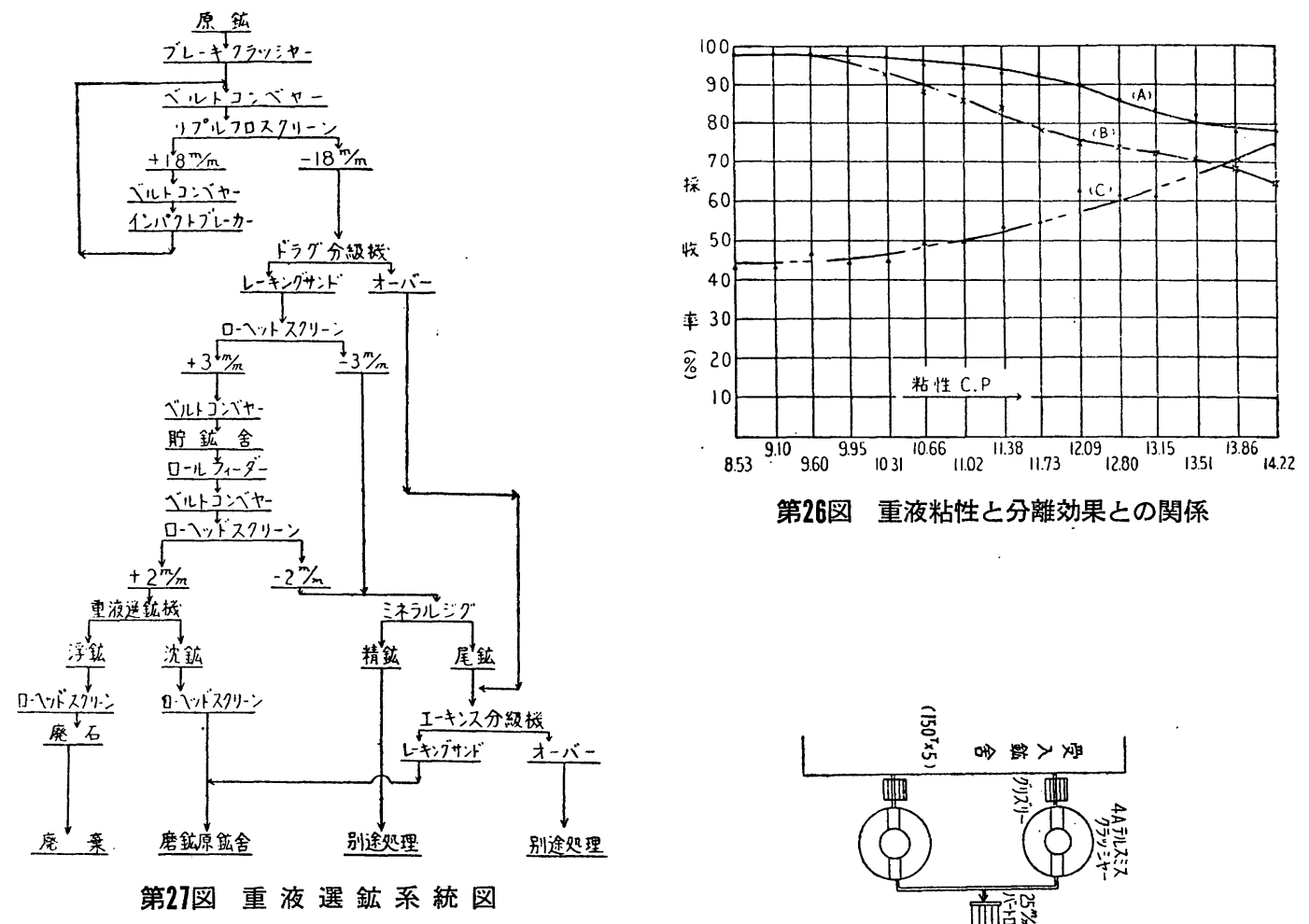

第26図 重液粘性亡分離効果との関係

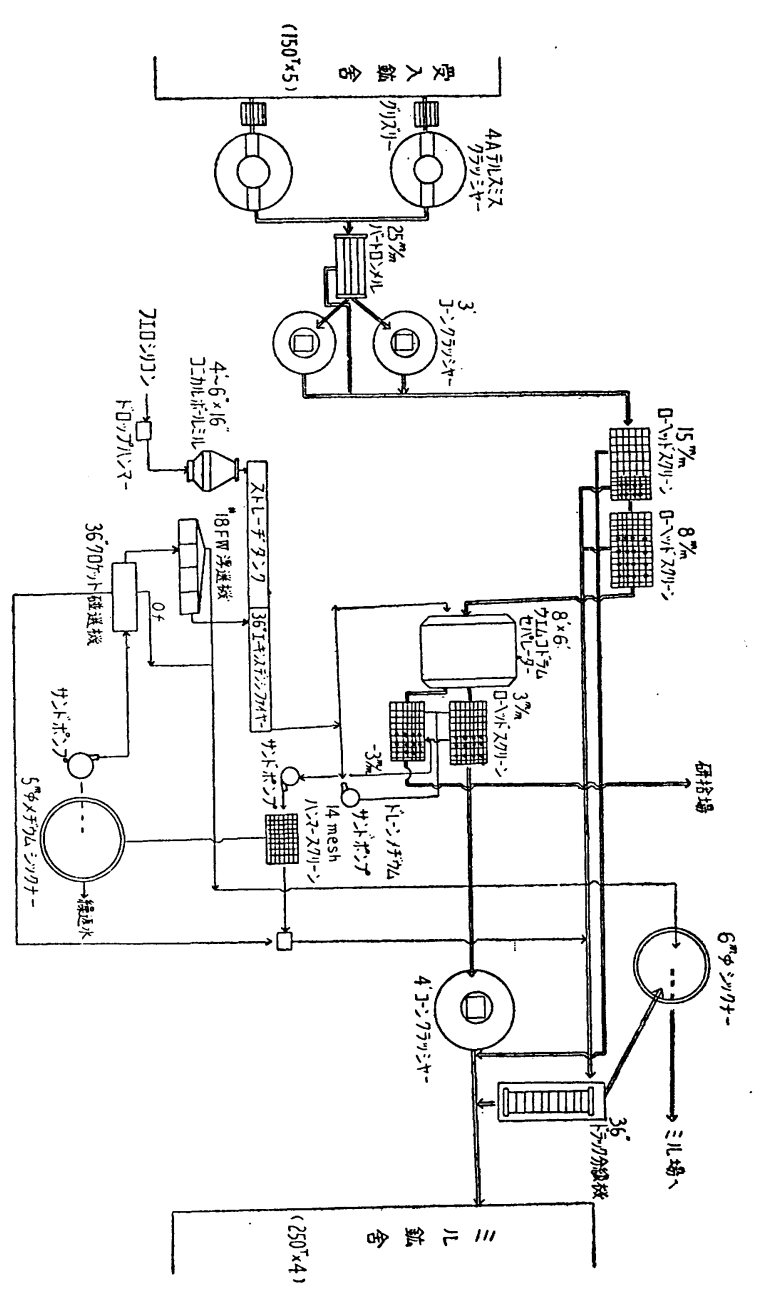

第28図重液材回収系統図

第29図 河山鉱業所粗碎重選関係系統図 


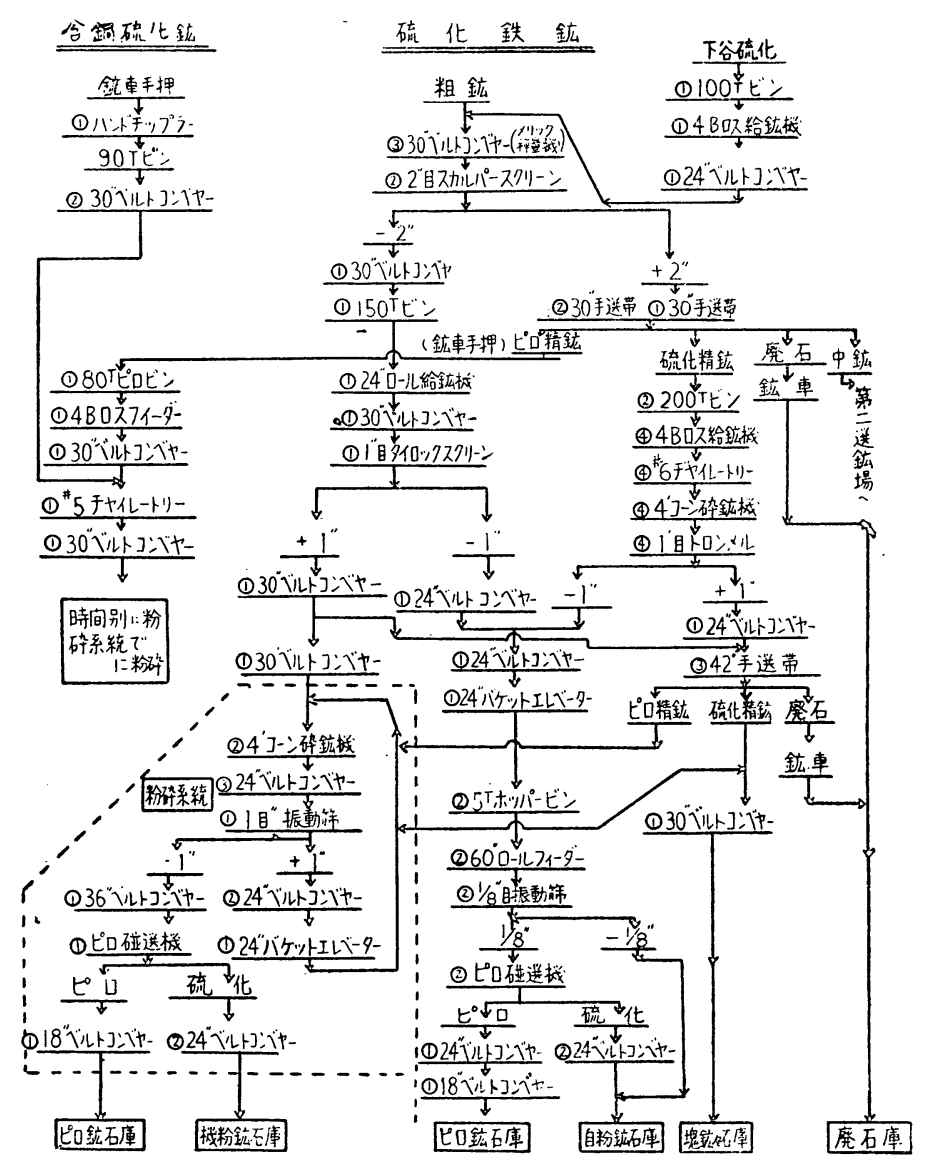

第 30 図相原鉱叢所第一選鉱系統図

第九表 重液選鉱機の種類並に仕様

\begin{tabular}{|c|c|c|c|c|c|c|c|c|}
\hline \multirow{2}{*}{ 摘 要 } & \multirow{2}{*}{ 粟村大谷 } & 鉄 興 社 & 東 邦 & 洋 & 鉱 & 日鉱 & \multicolumn{2}{|c|}{ ラ サ 田 老 } \\
\hline & & 稲 倉 石 & 対州 & 見 & 山 & 尾 小屋 & コーン型 & スパイラル型 \\
\hline 型 式 & $\begin{array}{l}\text { 外ーン型開部 } \\
\text { エャリフト式 }\end{array}$ & $\begin{array}{l}\text { 外ーン部 } \\
\text { エャリフト式 }\end{array}$ & \begin{tabular}{|l} 
外ーン型 \\
エャリフト式
\end{tabular} & フルバツク & $\begin{array}{l}\text { ジングル } \\
\text { ドラム }\end{array}$ & エーキンス & コーン型 & スパイラル型 \\
\hline 台 数 & 1 & 1 & 1 & 1 & 1 & 1 & 1 & 1 \\
\hline$x-カ-$ & 三恵工作所 & 足尾製作所 & 川口製作所 & 田川製作所 & 住友機械 & 横山工業 & 自家製 & 自家製 \\
\hline 大きさ & $5^{\prime} \phi \times 5$ & $4^{\prime}$ & $5.5^{\prime} \phi \times 60^{\circ}$ & $\begin{array}{l}1200 \times \\
1100 \times \\
5380\end{array}$ & $8^{\prime} \times 6^{\prime}$ & $\begin{array}{l}\text { ス゚イラル } \\
10.60 \phi \times 5.3 \mathrm{~m} \\
\text { タンク } \\
1,22 \times 5.7 \mathrm{~m}\end{array}$ & $\begin{array}{c}1,520 \phi \times \\
1,400 \\
\text { 頂角 } 60^{\circ} \\
\end{array}$ & $\begin{array}{l}15^{\prime \prime} \times 15^{\prime} \\
2 \text { 連 } 2 \text { 重 }\end{array}$ \\
\hline $\begin{array}{l}\text { 能 力 } \\
\mathrm{t} / \mathrm{hr}\end{array}$ & $\begin{array}{lr}\text { 最大平均 } & 15\end{array}$ & 12 & 25 & 20 & 76 & 60 & 25 & 15 \\
\hline 其 他 & & & & & $\begin{array}{l}\text { F゙ラム } \\
1.25 \text { r.p.m } \\
\text { モータ. } \\
7.5 \mathrm{P}\end{array}$ & 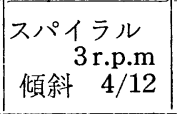 & & \\
\hline
\end{tabular}




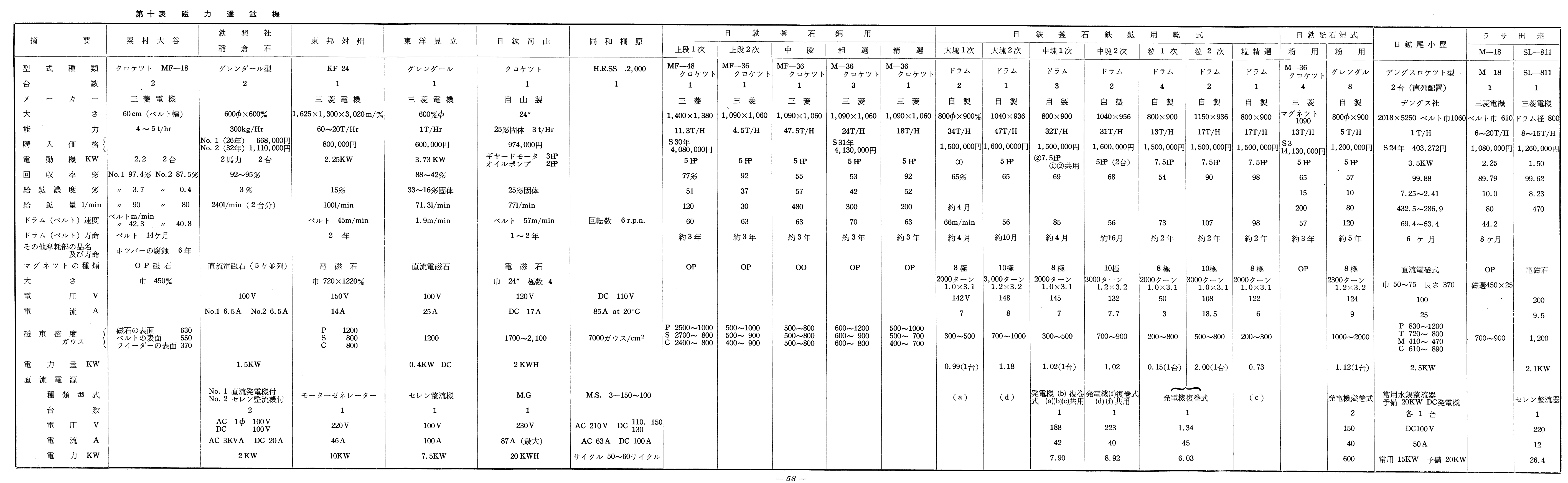


第十一表 重旅村及ひをの消费是

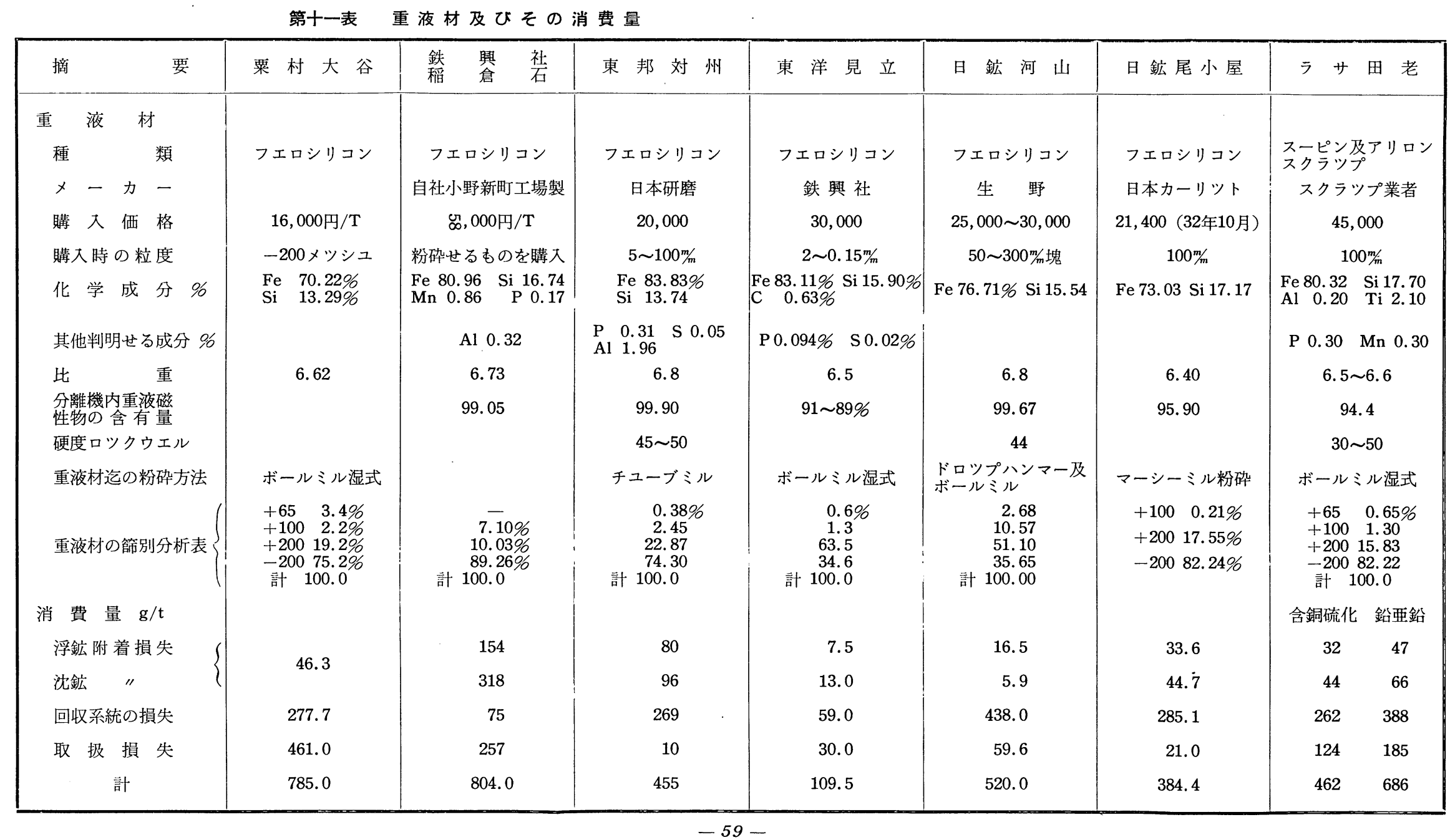




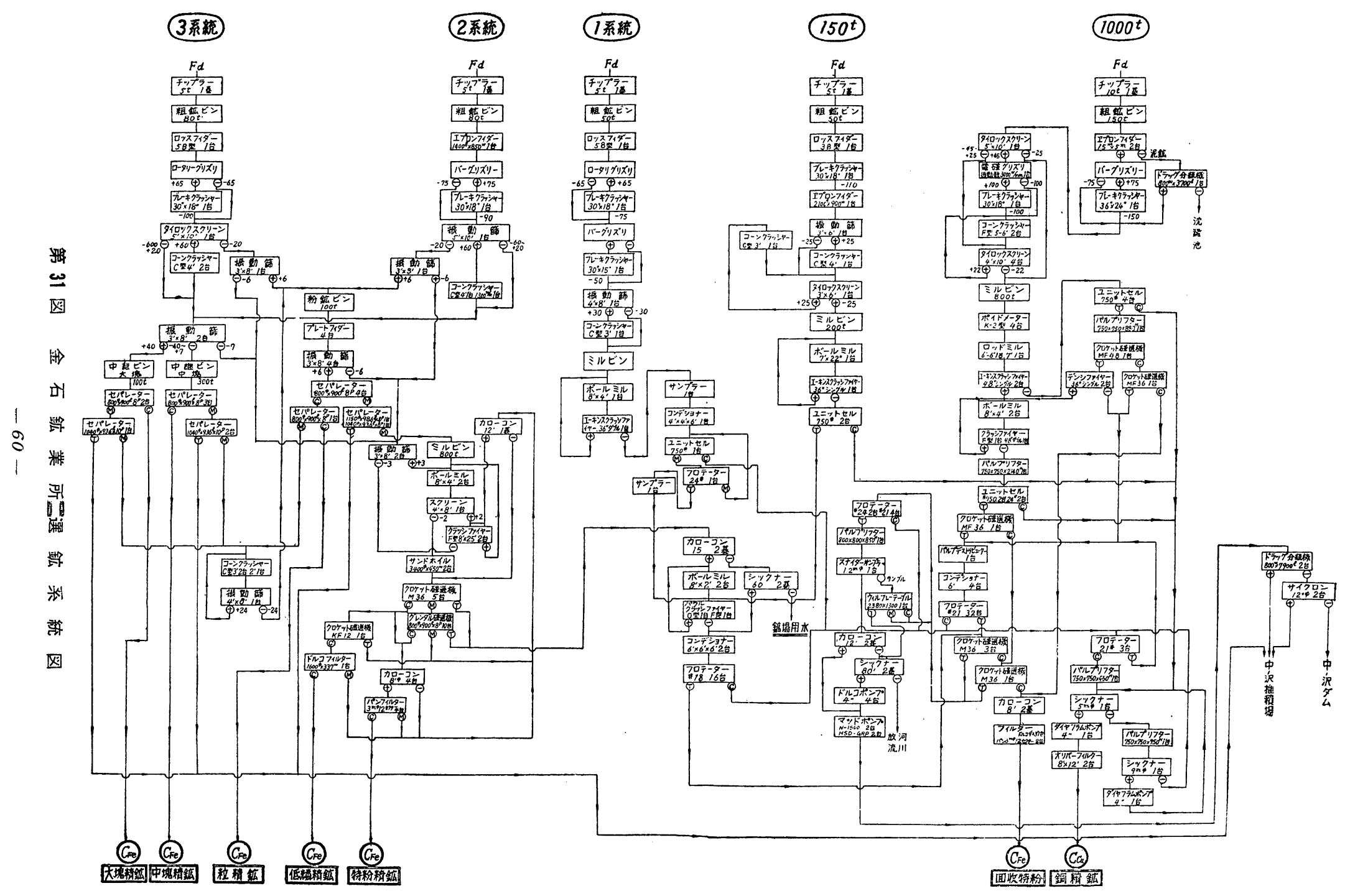




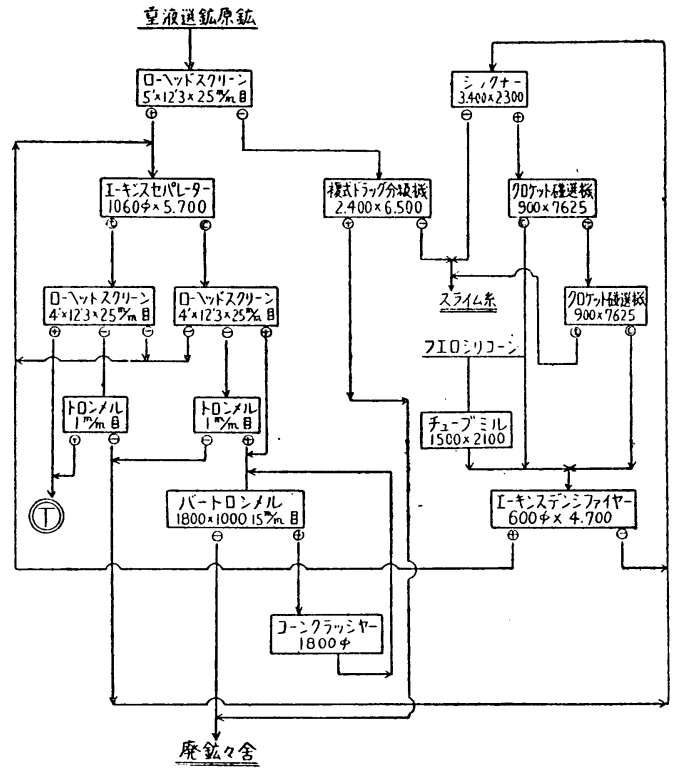

第32図 重液選鉱系統図

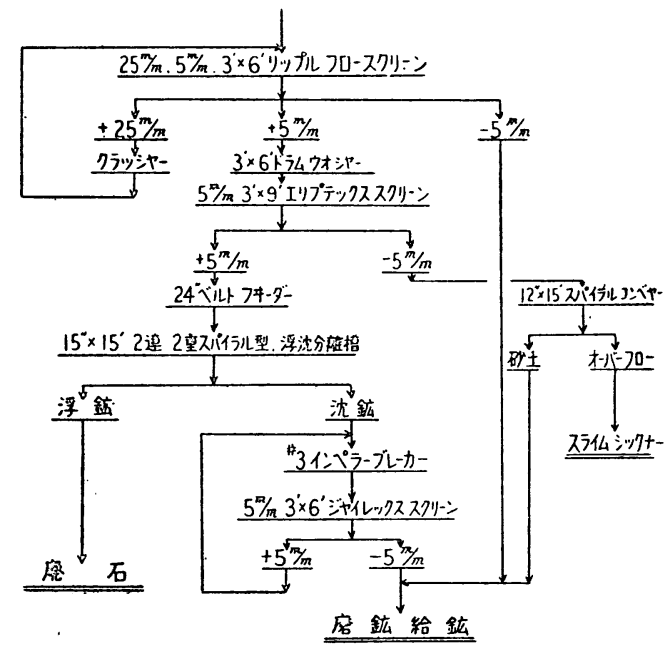

第3㤏 重液系統図（鉊、亜鉊鉱）

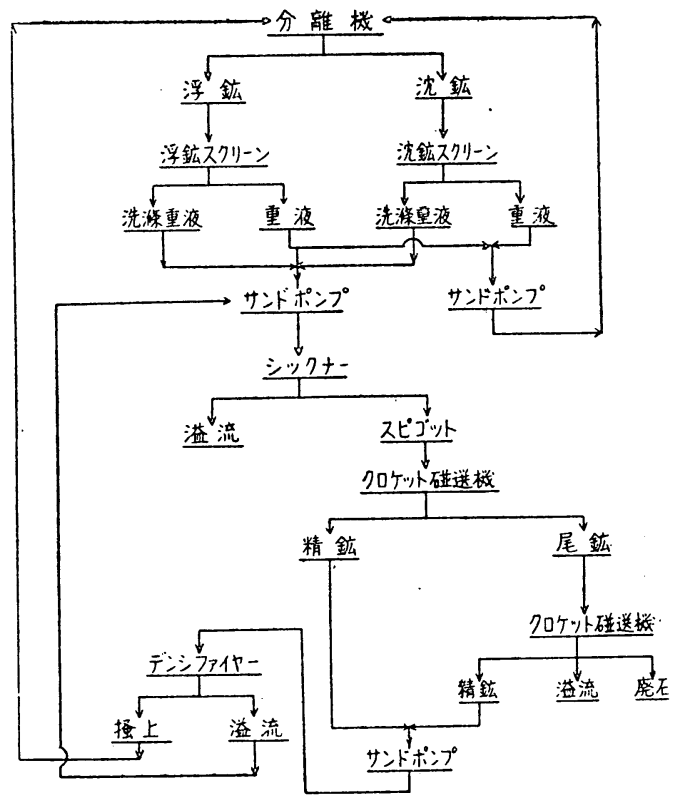

第33図 重液材の浄化回収系統図

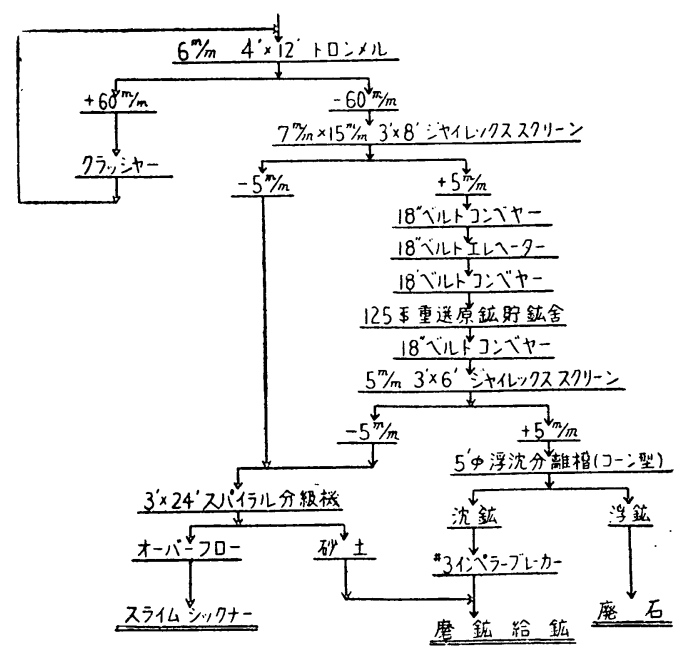

第35図 重液系統図（含銅硫化鉄鉱） 


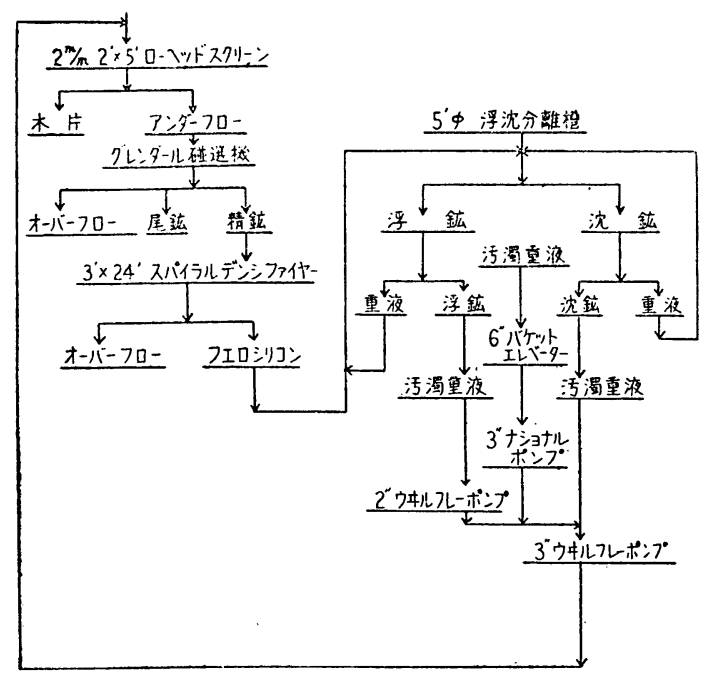

第36図 含銅硫化鉄鉱処理系統

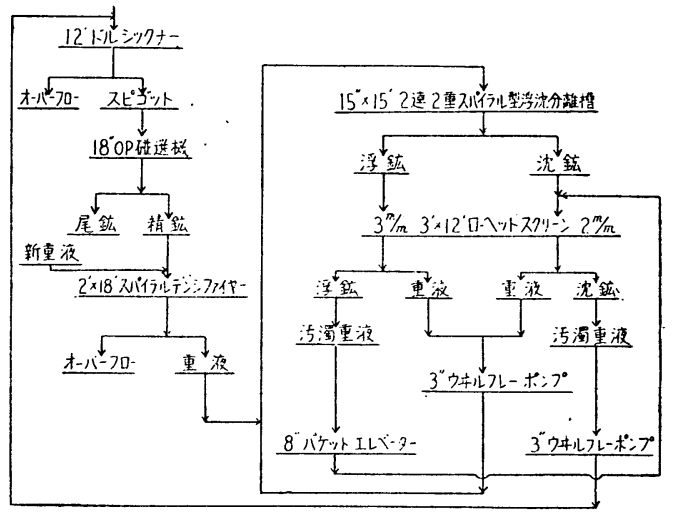

第37図 鉊、垔鉊鉱処理系統

る。

粘度上昇の原因は大部分は原鉱中の磁硫鉄鉱が混入乙 メヂア比重 5.5 程度に低下することによる。

（1）現設備の欠陥の点及び今後成績向上の為の対策等 についての意見

(A) 粟村鉱業大谷鉱山

セットリング・タンクのオーバフローは少し濁つてい て、一325メッシユ程度のフエロシリコンが流失してい るようであるので、セットリング・タンクの容量を增す 事又、マグネタイザー及びデクマグネタイザーの使用に ついても研究したい。

又休転時重液コーンより排出したフエロシリコンの貯 蔵に使用しているピットが小さいのでフエロシリコンが 流失し勝ちである。この流失量は取扱損失の相当の部分 を占的てると思われるので、フエロシリコンの流失を 防ぐためにピツトを大きくする。

(B) 東洋鉱山見立鉱業所

(1) 採掘粗鉱の性質上, 取扱鉱石以酸化鉱 7 ：硫化鉱 (39頁より続く)

文献

1. 久保秀正 : 磁硫鉄鉱処理方法の改善（日鉱誌、昭和 32 年11月）

2. 松野一喜: 河山鉱業所選鉱の特異性について（浮選 第 4 号)

3. C.S. Chang. S. R. Cooke. I. Iwasaki; Flotation Characteristic of Pyrrhotite.(Min Eng. Feb. 1954)

4. 早瀬喜太郎、原田種臣：磁硫鉄鉱の特性飞ついて(1)

（日鉱誌、昭和 26 年 3 月）

5. “ : " (2) (" 昭和 27 年 7 月)

6. “ : " (3) (" 昭和27年11月)

7. “ ; " (4) (" 昭和 28 年 4 月)

3 の割合に逆転した関係上原鉣洗條が問題となつている （現在ウオツシャーなし）

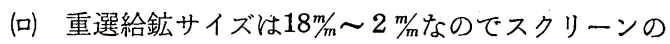
目詰りを生じ易い,

けy 貯液槽内のメヂウムを揽拌するのとブローだけで あり㩭拌装置がないので時間を要する（運転準備時間平 均 2 時間)

(二) 磁選璣の回収率が悪い。

(C) 日本鉱業河山鉱業所

$15 \mathrm{~m} / \mathrm{m}$ スクリーン網上産物（重選原鉱）を $\left(5^{\prime} \times 10^{\prime} 8 \mathrm{~m} / \mathrm{m}\right.$ 目）スクリーンでスプレーにより水洗しているが, 偏平 鉱の裏面括よびスプレ一の目詰り等のために水洗效果は 完全とは云克ず，かつ水洗効果を上げるためには水量が 増加する。この点ドラムワシャーを使用すれば原鉱中に 混入する細粒の沈涤が完全化し、メデアの污濁更には粒 度上昇による分離効果の低下を防止することが可能とな り、使用水量減によるスライム処理系統も容易になるも のと考光られる。

8. " : " (5) (" 昭和 32 年 8 月)

9. 武中俊三 : 磁硫鉄鉱の磁性と鉱床について(1)

（日鉱誌昭和30年10月）

10. “ : " (2) ( " 昭和30年11月)

11. D. A. Kiskyras; Untersuchen der magnetischen Eigenschaften des Magnetkies bei verschiedenen Temparaturen in besonderen Hinblick auf seine Entstehung

12. 吾妻潔：磁硫鉄鉱の発熱現象

（日釷誌 昭和 28 年 4 月）

13. 藤森正路：磁硫鉄鉱の自然発火現象について

（住友鉱山技枊 30 号） 